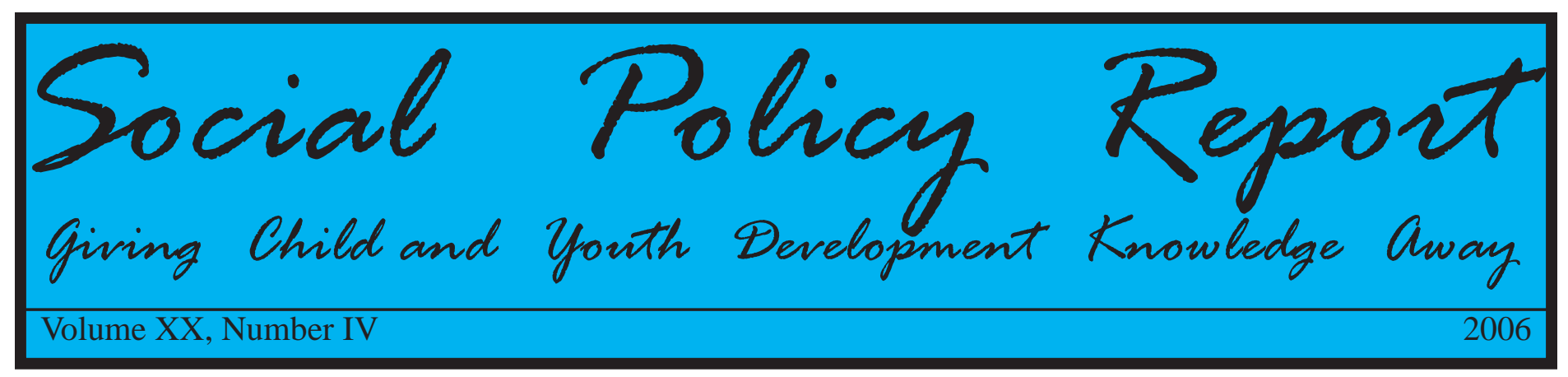

\title{
Organized Activity Participation, Positive Youth Development, and the Over-Scheduling Hypothesis
}

\author{
Joseph L. Mahoney, Angel L. Harris, and Jacquelynne S. Eccles
}

\begin{abstract}
There is increasing awareness that how young people spend their time outside of school has consequences for their development. As part of this awareness, interest in organized activities—extracurricular activities, after-school programs, and youth organizations - has grown markedly. On balance, the bulk of research on organized activities has shown positive consequences of participation for academic, educational, social, civic, and physical development. This fact, coupled with the safety and supervision provided by organized activities for youth with working parents, has fueled initiatives at the local, state, and Federal levels to expand opportunities for participation.

In seeming opposition to these initiatives, there exists concern that participating in organized activities has become excessive for youth. This "over-scheduling" is thought to result from pressure from adults (parents, coaches, teachers) to achieve and attain long-term educational and career goals. These external pressures, along with the activity-related time commitment, are believed to contribute to poor psychosocial adjustment for youth and to undermine their relationships with parents. Because the implication is that increasing amounts of organized activity participation will be harmful to youth and family functioning, attention from scientists, practitioners, and policymakers is warranted.

To evaluate these two somewhat different perspectives, we review two types of evidence: evidence from published studies focused on regional, historical, or limited samples and evidence from a very recent nationally representative sample of America's 5- to 18-yearolds that includes both time use data and information on a wide range of indicators of development. The main findings across studies are as follows:

(1) The primary motivations for participation in organized activities are intrinsic (e.g., excitement and enjoyment, to build competencies, and to affiliate with peers and activity leaders). Pressures from adults or educational/career goals are seldom given as reasons for participation;

(2) American youth average about 5 hours/week participating in organized activities. At any given time, roughly $40 \%$ of young people in the US do not participate in organized activities and those who do typically spend less than 10 hours/week participating. Many alternative leisure activities (e.g., educational activities, playing games, watching television) consume as much or considerably more time. However, a very small subgroup of youth (between 3 and 6 percent) spends 20 or more hours/week participating;

(3) There is quite consistent and strong evidence of a positive association between participating in organized activities and a variety of indicators of positive development: those youth who participate demonstrate healthier functioning on such indicators ranging from academic achievement, school completion, post secondary educational attainment, psychological adjustment, and lowered rates of smoking and drug use, to the quantity and quality of interactions with their parents. As the amount of participation in organized activities increases, the evidence suggests that the associated benefits of participation are observed either to accrue across the full range of activities or weekly hours of participation considered or to level off at relatively high amounts of participation; and

(4) Concerning the well-being of youth with very high levels of involvement in organized activity participation (e.g., 20 or more hours/week), indicators of adjustment tended either to be more positive than, or similar to, youth who did not participate. Only a very few indicators of well-being have been shown to decline to a level significantly lower than youth who did not participate in organized activities.

In sum, given the very limited empirical support for the over-scheduling hypothesis and the quite consistent support for the positive youth development perspective, we recommend that the recent efforts to expand opportunities for organized activity participation should stay the course. For the vast majority of young people, participation is associated with positive developmental outcomes. Of greater concern than the over-scheduling of youth in organized activities is the fact that many youth do not participate at all. The well-being of youth who do not participate in organized activities is reliably less positive compared to youth who do participate.
\end{abstract}




\section{Social Policy Repout}

Editor

Lonnie Sherrod, Ph.D. sherrod@fordham.edu

\section{Associate Editor}

Jeanne Brooks-Gunn, Ph.D. brooks-gunn@columbia.edu

\section{Director of SRCD Office for Policy and Communications \\ Mary Ann McCabe, Ph.D. mmccabe@srcd.org}

\section{Managing Editor}

Stephanie J. Church

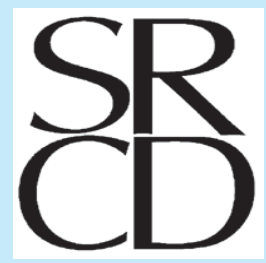

\section{GOVERNING COUNCIL}

Aletha Huston Arnold Sameroff Ross D. Parke Judith G. Smetana Ronald G. Barr Marc H. Bornstein Alysia Blandon

Jeanne Brooks-Gunn Greg J. Duncan John W. Hagen Suniya Luthar Ann Masten Robert B. McCall Ellen E. Pinderhughes J. Steven Reznick

POLICY AND

\section{COMMUNICATIONS COMMITTEE}

Marilou Hyson

Martha Zazlow

Cheryl Boyce

Jeanne Brooks-Gunn

Kristen Bub

Greg J. Duncan

Dale Farran

Barbara H. Fiese

\section{PUBLICATIONS COMMITTEE}

Rachel Keen

Mary Cwik

Sandra Graham

Joan Grusec

Aletha Huston

Brenda Jones Harden

\section{From the Editor}

In this issue of the Social Policy Report, Mahoney, Harris, and Eccles examine the literature on organized after-school activities and present new data as to whether some parents over-schedule their children in out-of-school activities.

After-school programming has grown in popularity and received increased federal support during the past decade. This is good news. After-school programs, if nothing else, provide an important child-care role. The workday of most parents is longer than the school day, so we need to make provisions for the care of children of all ages during this time. There is substantial research showing that leaving children to their own during this time-latchkey children-places them at risk. However, because after-school time has implications for children's success in school, it is wise and desirable to make constructive use of this time. Mahoney et al. point out that generally, participation in organized after-school activities carries positive benefits for children and youth.

After-school programming also addresses an equity issue. Mahoney et al. point out that some $40 \%$ of youth do not participate in after-school activities. More affluent families have often provided their children with after-school enrichment activities in art, music, and sports. The popular media label "soccer moms" reflects this fact. We then usually assume that all is well with such youth. Suniya Luthar, who provides a commentary in this issue addressing her work, has shown that this is not necessarily true; affluent youth can also be at risk, just for different reasons than disadvantaged youth are at risk. Similarly in after-school activities, there has been concern that affluent youth are being pushed to do too much so that it has negative consequences as a result. Mahoney et al. present original data addressing this overscheduling hypothesis and conclude that this occurs only in a single-digit percent of youth and that there is little evidence these young people develop problems as a result of their participation. Generally the soccer moms have it right and organize after-school activities that benefit their children.

Mahoney et al.'s data on the over-scheduling hypothesis make it even more important that we rigorously develop after-school programming for disadvantaged youth. However, to do so requires substantial new research such as that presented in this SPR. Out-of-school time can be used for homework help and other curriculum-related activities to impact school performance and/or it can be used for extracurricular or enrichment activities. Programs are not always clear about their goals, and even if they have clear goals, their curriculum sometimes does not match the goals. Sometimes programs are evaluated for academic benefits when they in fact offer few academic activities and vice versa. The need for after-school programming has caused policy to expand beyond what we know from research. Research is needed that addresses how different kinds of program activities map onto different outcomes and what kinds of activities different youth need. Only with such research in hand can we expand after-school programming in the most effective manner. Commentaries by Reed Larson and Jodie Roth address relevant research issues.

Brooke and I hope that this issue serves to promote the expansion of afterschool programming to reach that $40 \%$ not now being served. Furthermore, we hope that it promotes research by SRCD members and others on how to most effectively design and use out-of-school activities. Because of the importance of this issue, and the authors' presentation of new data, which is unusual for the $S P R$, this issue is longer than most, almost double the size. We thank SRCD for agreeing to support this increased size.

Lonnie Sherrod, Ph.D., Editor Fordham University 
Organized Activity Participation,

Positive Youth Development, and the

Over-Scheduling Hypothesis

\section{Joseph L. Mahoney, Yale University}

Angel L. Harris, University of Texas at Austin Jacquelynne S. Eccles, University of Michigan

School-aged children in the US and other Western nations average $40-50 \%$ of their waking hours in discretionary activities outside of school (Hofferth \& Sandberg, 2001a; Larson \& Verma, 1999). There has been increasing awareness that how young people use this time has consequences for their development. As a result, research on the risks and benefits of a variety of after-school activities has been expanding rapidly and considerable attention has been devoted to school-age children's (ages 5-11) and adolescents' (ages 12-18) involvement in organized activities (Mahoney, Larson, \& Eccles, 2005). Organized activities occur outside of the school day and are characterized by structure, adult-supervision, and an emphasis on skill-building. Common activities include school-based extracurricular activities (e.g., sports, clubs, and fine arts), after-school programs (i.e., programs, often targeted to youth between the ages 5-14, that provide participants with adult supervision during the afternoon hours while many parents are working and offer opportunities for academic assistance, recreation, and/or enrichment learning) and community-based programs and youth organizations (e.g., 4-H, Boys \& Girls Clubs of America, and Girls, Inc). Organized activities can be contrasted with alternative ways that young people spend their discretionary time such as educational activities, household chores, watching television, playing games, hanging out, and employment.

Participation in organized activities is a common developmental experience for young people (Cappizzano, Tout, \& Adams, 2000; Lugaila, 2003). For example, the 1999 National Survey of America's Families (NSAF) reported that $81 \%$ of 6 - to 11 -year-olds and $83 \%$ of 12 - to 17-year-olds participated in one or more sports, lessons, or clubs during the past year (Ehrle \& Moore, 1999; Moore, Hatcher, Vandivere, \& Brown, 2000). Approximately 7 million children are enrolled in after-school programs (Afterschool Alliance, 2005; Capizzano et al., 2000). Millions more participate in community-based programs and youth organizations such as 4-H, Boys \& Girls Clubs of America, and Girls Inc. (Boys \& Girls Clubs of America, 2004; Girls Inc., 2004; U.S. Department of Agriculture, 2003). Moreover, national studies show that participation in some organized activities such as sports and before/afterschool programs has increased significantly in recent years (Capizzano et al., 2000; Hofferth, \& Sandberg, 2001b; Seppanen, Love, de Vries et al., 1993).

The growth of organized activities has resulted from several factors. First, there has been an expansion of local, state, and Federal expenditures to support organized activities (Pittman, Tolman, \& Yohalem, 2005; Quinn, 2005). A well-known example is the increase in Federal support for 21st-Century Community Learning Center grants that support after-school programs. This funding grew exponentially from $\$ 40$ million in 1998 to $\$ 1$ billion in 2002 (Mahoney \& Zigler, 2006). Second, the historic rise in maternal employment (U.S. Department of Labor, 2005) has resulted in a gap between the school day of children and work day of their parents. This fact, coupled with research pointing to dangers for children who are unsupervised during the after-school hours (e.g., Pettit, Bates, Dodge, \& Meece, 1999; Richardson, Radziszewska, Dent, \& Flay 1993; Vandell \& Shumow, 1999), has called attention to organized activities as a means to provide safety and supervision for children with working parents (McLaughlin, 2000). Finally, on balance, the bulk of research on organized activities has shown positive consequences of participation for academic, educational, social, civic, and physical development (for reviews, see Dubois, Holloway, Valentine, \& Cooper, 2002; Eccles, Barber, Stone, \& Hunt, 2003; Eccles \& Templeton, 2002; Mahoney et al., 2005; National Research Council and Institute of Medicine, 2002; Riggs \& Greenberg, 2004; Vandell, Pierce, \& Dadisman, 2005).

In combination, these factors have increased awareness that organized activities represent a valuable resource for promoting positive youth development. This is evident in the out-of-school initiatives of major research intuitions (e.g., Chapin Hall Center for Children, Harvard Family Research Project), granting institutions and foundations (e.g., C. S. Mott Foundation, W. T. Grant Foundation), advocacy and lobbying groups (e.g., Afterschool Alliance, Fight Crime Invest in Kids, National Institute on Out-ofSchool Time, National School-Aged Care Alliance), as well as the initiation of a bipartisan Congressional Afterschool Caucus in March 2005.

\section{The Over-Scheduling Hypothesis}

At the same time that initiatives to expand opportunities for organized activity participation have been increasing, concern exists that some youth are participating in too many organized activities. Written and televised media re- 
ports (e.g., Fountain, 2005; Gilbert, 1999; Noonan, 2001) and popular parenting books (Elkind, 2001; Rosenfeld \& Wise, 2000) suggest that the lives of many young people are now replete with hurry, stress, and pressure brought on, in part, because of their involvement in too many organized activities. These articles maintain that an over-scheduling of organized activity participation may undermine family functioning and youth well-being.

With respect to organized activities, the over-scheduling hypothesis is based on three interrelated propositions. First, the motivation for participation in organized activities is viewed as extrinsic. Youth are seen as taking part in a variety of activities because of the perceived pressure from parents or other adults to achieve and attain long-term educational and career goals (e.g., a college scholarship). Second, the time commitment required of children and parents to participate in organized activities is believed to be so extensive that traditional family activities - dinnertime, family outings, and even simple discussions between parents and children-are sacrificed. Finally, owing to the assumed pressures from parents, coupled with the extensive time commitment and disruption of family functioning, youth devoting high amounts of time to organized activity participation are thought to be at risk for developing adjustment problems and poor relationships with parents.

Although the basis for these propositions has been seldom anchored by empirical research, scientific evidence has been used to advance the notion that some youth (particularly middle class and affluent youth) are overscheduled in some cases and that such over-scheduling can be detrimental to the optimal development of young people and their families (e.g., Lareau, 2003; Rosenfeld \& Wise, 2000). This evidence draws on qualitative studies of how organized activity participation affects family life and quantitative studies suggesting that perceived pressure from parents and other adults (e.g., coaches, teachers) may lead to poor adjustment particularly for affluent youth (i.e., families whose annual household earnings are at least twice as high the medium annual income for families in the US) (e.g., Luthar \& Latendresse, 2005). As far as we know, the argument has not been directed to poor or working-class youth and there have been no studies of this issue focused on less advantaged populations.

Whether youth participate in organized activities depends, in part, on the behavior of their parents. Studies of children and adolescents suggest that they are more likely to become involved and to stay involved in organized activities when parents value and encourage their participation, provide the necessary material resources, and are participants themselves (e.g., Fletcher, Elder, \& Mekos, 2000; Fredericks \& Eccles, 2005; Simpkins, Davis-Kean, \& Eccles, 2005). However, a recent ethnographic study conducted with children (ages 910) from 12 diverse families suggests that organized activity schedules can determine the pace of life for all family members (Lareau, 2003). The findings from Lareau's study show that the time budgeting and schedule commitments required of parents to support their children's activity participation can be challenging-particularly for working parents with several children. The qualitative accounts also suggest that participation in many organized activities can limit children's down time and constrain the nature parent-child interactions. While her study has been used to justify the inference that such scheduling might be problematic, Lareau did not actually investigate the children's well-being. Moreover, a systematic evaluation of how time spent in organized activities may affect discretionary time or parent-child interactions was not a goal of this study. Finally, although provocative, the findings are based on a small number of families and this raises concern about whether the results can be generalized beyond the study sample.

Quantitative studies suggesting possible risks for affluent adolescents have also been cited in support of the over-scheduling hypothesis. For example, in one of a few relevant studies, Luthar and her colleagues concluded, first, that adolescents (6th and 7th graders) from affluent homes can be at greater risk for substance use, depression, and anxiety as they enter adolescence than children living in less affluent homes, and, second, that excessive achievement pressures and isolation from parents may help to explain these associated risks (Luthar \& Becker, 2002; 
Luthar \& Latendresse, 2005a, b). However, this research did not assess the association between time spent participating in organized activities and achievement pressures or adolescent adjustment. Accordingly, these studies neither intended to nor do they provide evidence that adolescents (affluent or otherwise) perceive pressure to participate in organized activities from their parents or are at-risk for adjustment problems as a result of their participation.

Our interest in conducting an evaluation of the scientific underpinnings of these propositions is twofold: First, these propositions suggest negative consequences resulting from too much organized activity participation. This has the potential to undermine recent efforts to support and expand opportunities for youth to participate in organized activities. Because policy decisions concerning children and families will be made with or without the use of scientific knowledge (Shonkoff, 2000), this concern holds despite the limited evidence on which the over-scheduling hypothesis is based. Indeed, the response to findings from the national evaluation of 21st-Century Community Learning Centers show that substantial reductions in funding for organized activities can be proposed on the basis of a single study with controversial findings (Mahoney \& Zigler, 2006).

Second, despite research available to inform propositions of the over-scheduling hypothesis, the scientific community has been relatively silent on this issue. As the value and worth of psychological research depends increasingly on an appropriate and timely integration of science with policy (McCall \& Groark, 2000; Huston, 2005), it is essential that the existing research informing this matter be communicated. To that end, one of our major goals is to evaluate the scientific basis of the over-scheduling hypothesis. Our second major goal is to evaluate the evidence for the alternative positive youth development perspective; namely, that participation in organized activities facilitates positive development and that more participation is associated with more positive development. First, we review what is known about the reasons why American young people participate in organized activities. Second, we examine the extent of American children's/adolescents' participation in organized activities in terms of the amount of time and the number and/or breadth of activities. Finally, we summarize research that has considered the association between increasing participation and a variety of indicators of youth development, particularly during adolescence. We conclude by discussing implications that follow from the research.

\section{Why Do Young People Participate in Organized Activities?}

The over-scheduling hypothesis proposes that youth often participate in organized activities because of pressure from adults to achieve and attain long-term educational/ career goals. Several studies have investigated why youth participate in a variety of organized activities ranging from extracurricular activities (e.g., sports, art, science, and civic activities), community-based organizations (e.g., Boys \& Girls Clubs, Girls Inc., YMCA), and after-school programs. Across these studies, participants ranged in age from 9- to 19-yearsold and were diverse in race/ethnicity and economic background. The methodological approach typically involved asking youth to describe the reasons for their participation on an individual basis or as part of adultled focus groups. The most common reasons both adolescents and preadolescents give for participation include: a) enjoyment and excitement (Csikszentmihalyi, Rathunde, \& Whalen, 1993; Passmore \& French, 2001; Gambone \& Arbreton, 1997); b) encouragement and support received from friends or parents (Fletcher et al., 2000; Huebner \& Mancini, 2003; Raymore, Godbey, \& Crawford, 1994; Simpkins et al., 2005); c) opportunities to challenge oneself, build skills, and increase self worth (Carruthers \& Busser, 2000; Gambone \& Arbreton, 1997; Perkins, Borden, Villarruel et al., 2006); d) desire to interact with activity leaders and age mates (Huebner \& Mancini, 2003); and e) personal safety (Borden, Perkins, Villarruel, Carleton-Hug, Stone, \& Keith, 2006; Gambone \& Arbreton, 1997).

Thus, although there are many reasons that underlie youth participation in organized activities, the most common motivations are intrinsic. In opposition to the over-scheduling hypothesis, youth seldom describe pressure from parents or long-term educational/career goals 
as the primary reasons for participating. This holds for talented and highly involved adolescents, those living in suburban areas, and adolescents from economically advantaged backgrounds. For example, in study of 314 affluent, suburban 8th-grade students (Luthar, Shoum, \& Brown, 2006), youth reported the number of hours spent in organized activities as well as the reasons for their participation including enjoyment, expediency (e.g., good for my future), and pressure (e.g., adults want me to). Results showed that the primary reasons for participation were enjoyment and expediency; external pressure was mentioned least often. Similarly, Csikszentmihalyi et al. (1993) assessed reasons for activity participation in a sample of 208 9th and 10th graders drawn from two large, suburban high schools that served students from economically diverse backgrounds. Students were selected for the study on the basis of enrollment in accelerated or advanced classes and having been nominated by a teacher for talent in math, science, music, athletics, and/or art. Results showed that intrinsic reasons (e.g., "I

like it," "it interests me") were ranked highest, followed by extrinsic reasons focused on material rewards (e.g., "it will be useful for my future") and social rewards (e.g., "it impresses other people"). Finally, Fredricks, AlfeldLiro, Hruda, Eccles, Patrick, and Ryan (2002) conducted a qualitative study of reasons why adolescents persist or drop out of extracurricular activities. Drawn from the Childhood and Beyond Study, the sample included 41 middle-class, White adolescents in Grades 9, 10, and 12 who were selected on the basis of being highly involved in activities and competent during childhood. The most common reasons adolescents reported for participating in an activity was enjoyment, followed by "being good at it" and having the opportunity to see friends. A minority of participants also mentioned participating to please their parents, coaches, or teachers, or because they believed it could be useful in their future education or career.

Overall, these findings are consistent with modern perspectives on expectancy-value theory suggesting that activity choices are usually made on the basis of how important and relevant the activity tasks are to the individual, perceived expectations for success or failure at the activity, and whether participation is considered interesting and enjoyable (e.g., Eccles, Wigfield, Harold, \& Blumenfeld, 1993; Jacobs, Vernon, \& Eccles, 2005; Wigfield \& Eccles,
1992). However, few studies have assessed whether external motivators may be more common for certain subgroups of youth or whether the reasons for participation vary according to the type of activity considered. For example, among adolescent athletes and musicians participating at the highest levels of competition, perceived pressure from parents has been found to represent a source of competitive stress that predicts activity dropout (e.g., Averill \& Power, 1995; Fredericks et al., 2002; Leff \& Hoyle, 1995; Scanlan, 1984). The extent to which this is a common experience for elite competitors, applies to different types of activities, or characterizes other extreme subgroups of participants (e.g., youth who spend unusually high amounts of time participating) has not been examined systematically.

How Much Time Do Young People Spend in Organized Activities?

The over-scheduling hypothesis assumes that some youth participate in organized activities in excessive amounts. Although the amount of participation that constitutes such overscheduling has not been defined, it can be evaluated by relating how much time youth spend in organized activities to relevant indicators of their well-being. Accordingly, as a first step, we consider the number of hours youth devote to organized activities and other leisure pursuits using data from the Child Development Supplement (CDS) of the Panel Study for Income Dynamics (PSID).

The PSID began in 1968 as a nationally representative sample of 5,000 American families who were interviewed every year until 1997, after which data collection occurred on a biennial basis. Data collection includes members from the original families and families formed by children of the originally sampled families. In 1997, the PSID added the CDS to address the lack of information on children. Thus, the objective of the CDS was to provide a nationally representative longitudinal database of children and their families to support studies on the dynamic process of human development. The CDS consists of two waves: CDS-I contains 3,563 children between the ages of 0-12 sampled from PSID families in 1997. The follow-up wave (CDS-II), conducted in 2002-2003, involved 2,908 children between the ages of 5 and 18 whose families were still active in the PSID panel.

As part of CDS assessments, respondents completed time diaries that required them to document the time spent 


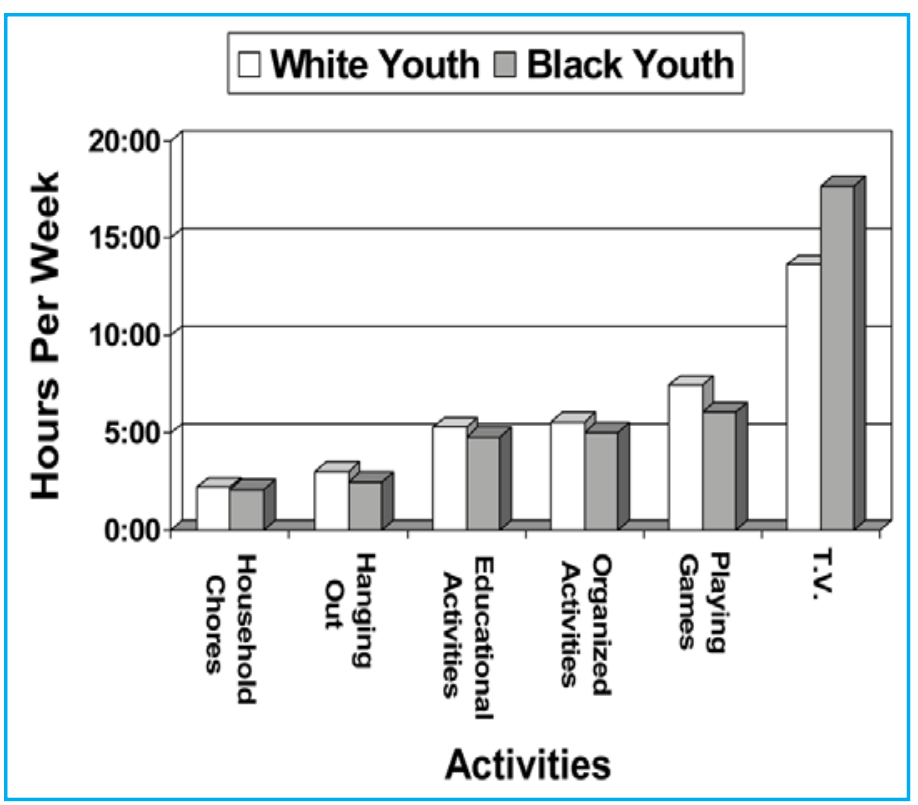

Figure 1. Weekly hours that White and Black youth (ages 5-18) spend in organized and non-organized activities.

on every activity during the course of a 24-hour period. Two time diaries were collected per child; one that was completed within three days of a designated weekday and the other within one week of a designated weekendday. For the youngest respondents (i.e., children who were younger than 9 years old) time diaries were often completed by a parent or cooperatively as a parent-child dyad. Older children and adolescents completed the time diaries on their own. The time diaries were reviewed and edited by interviewers and codes were created for each activity recorded. For this paper, we use only the time diaries from the second wave because these children were 5-18 years old at the time of testing. Due to the limited numbers of immigrant families and other ethnic groups, we further restricted our analyses to Whites $(n=1,144)$ and Blacks ( $n=981) .{ }^{1}$ We employed a weighting system devised by the PSID-CDS staff that adjusts for the effects of both the initial probability of being sampled and attrition over time - which is generally low - and incorporates a post-stratification factor to ensure the data are nationally representative. ${ }^{2}$ These data provide the only existing information on the time use of a nationally representative sample of young people in the United States and therefore is the only data set available with which to estimate the extent of over-scheduling for America's youth.

Figure 1 shows the activities we considered and the average weekly hours spent in each separately for Whites and Blacks (see Appendix A for activity descriptions). Weekly totals were calculated as the sum of average minutes during the weekday multiplied by five and average minutes during the weekend-day multiplied by two. Although our interest is in organized activities, we provide the same information for various other activities that occupy children's free time. On average, these youth-White and Black-spent about 5 hours per week in organized activities ${ }^{3}$-approximately the same amount of time they spent on out-of-school educational activities. They spent less time performing household chores and hanging out, but more time playing games and watching television.

Figure 2 shows the weekly average time spent on organized activities for Whites and Blacks by categories of parental education and age group (see Appendix B for the same information on other activities). ${ }^{4}$ Time spent participating in organized activities increased from childhood to adolescence. For Whites, such participation increased with parental education for each age group. However, the pattern for Black youth is less clear; for ages 5-11 and 12-14, youth whose parents had not graduated from high school spent more time in organized activities than those whose parents had a 4-year degree or greater. Thus, educated White parents may be especially likely to encourage their children's involvement in high levels of organized activity participation.

To determine the distribution of time that Black and White youth spent in organized activities, we created time categories with 5-hour increments ending with "20 or more hours," and we include "zero time" for those who did not participate. Figure 3 shows the proportion of youth within the six time categories (see Appendix $\mathrm{C}$ for the proportion of youth within these time categories for other activities). ${ }^{5}$ With the exception of Black children (ages 5-11), slightly more than $50 \%$ of all youth spent some time in organized activities. About 25\% of the adolescents (ages 12-18) spent 10 or more hours/week in organized activities. A relatively small percentage of these White and Black adolescents - $7 \%$ for ages $12-14$, 5\% for ages $15-18$ - spent 20 or more hours/week in organized activities.

In sum, organized activities do not dominate American young people's free time. Many alternative free time activities (e.g., educational activities, playing games, and watching television) consume as much or considerably more time. This conclusion is consistent with the broader literature on young people's time use and participation in active, structured leisure activities reviewed by Larson and Verma (1999). ${ }^{6}$ Nevertheless, a small percentage of 


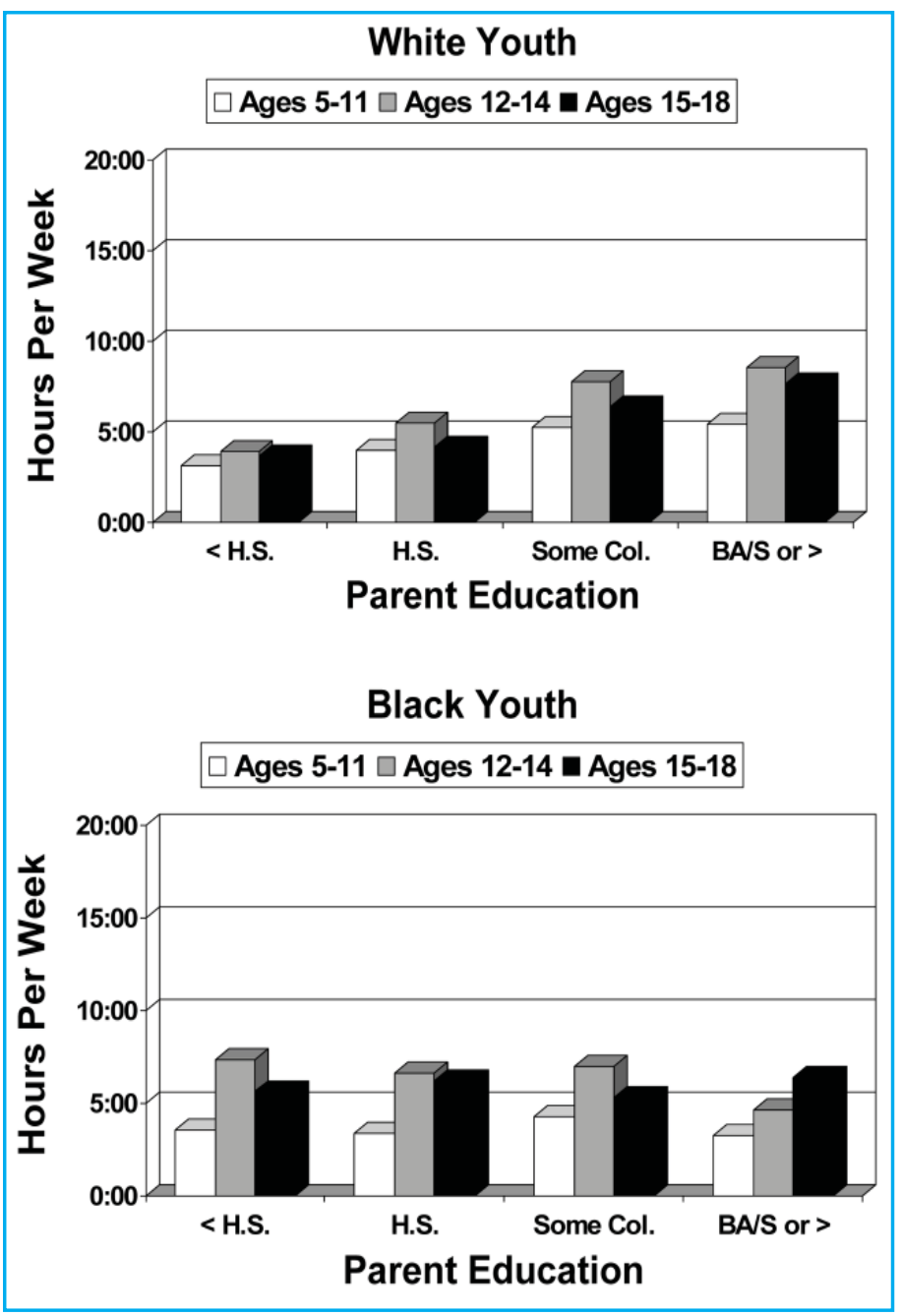

Figure 2. Weekly hours that White and Black youth spend in organized activities according to parental education and age.

week participating in organized activities. To determine whether the amount of activity has positive or negative consequences for development, we examined the association of the amount of time spent in organized activities with several indicators of adjustment.

\section{Does Organized Activity Participation Contribute to, or} Undermine, Positive Youth Development?

The over-scheduling hypothesis predicts that youth with very high amounts of organized activity participation will demonstrate poor adjustment relative to both those with little or no participation and those with more moderate amounts of participation. In contrast, positive youth development theory and research on organized activities suggest that increasing participation is linked to incremental benefits in a variety of positive developmental
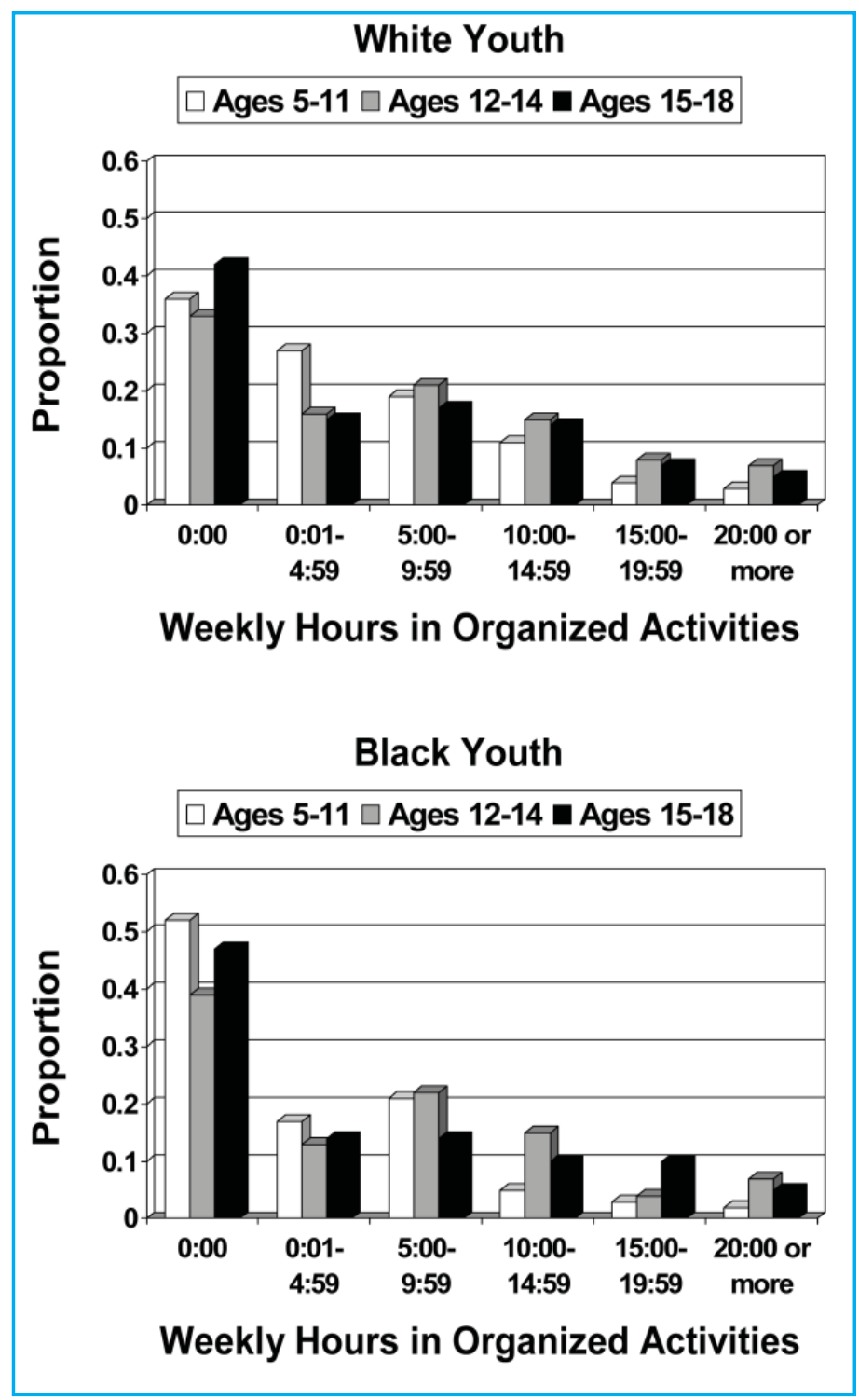

Figure 3. Proportion of White and Black youth participating in organized activities according to selected time categories (hours/week) and age.

experiences such as physical and psychological safety, supportive relationships with peers and adults, opportunities for belonging, positive social norms, support for efficacy and mattering, opportunities for skill building, and integration of family, school, and community experiences (e.g., Eccles \& Templeton, 2002; Mahoney, Eccles, \& Larson, 2004; National Research Council and Institute of Medicine, 2002). This literature predicts that participating in well-designed organized activities will facilitate positive adjustment and that these benefits will strengthen as the amount of time participating increases (though, at high amounts of participation, possibly to asymptote). To help resolve the controversy, we first summarize findings from 
existing studies that have considered the link between activity participation and young people's adjustment and then we return to the time-based categories from the PSIDCDS and associated outcomes.

Existing studies. A few studies have considered youth adjustment in relation to the amount of participation in organized activities. In this research, the amount of participation is defined either in terms of number of hours/week spent in organized activities or the number and/or breadth of activities participated in at one time. In this regard, the over-scheduling hypothesis can be framed in terms of either the number of hours/week or the total number of different activities because both too much time and too many activities can be construed as stressful and/or problematic for youth development. Thus, we include both types of studies in this review. Overall, both types of studies support the hypotheses that participating in organized activities facilitates positive youth development and that more participation is nearly always better than little or no participation. However, a few studies also suggest that there may be a point of diminishing returns for the small proportion of youth with extremely high levels of involvement.

Two studies have considered the amount of time (weekly hours) that youth spend in organized activities and indicators adolescents' well-being. First, Cooper, Valentine, Nye, and Lindsay (1999), in a cross-sectional study of 424 non-poor, mostly White students in Grades 6-12, reported a significant, positive association between number of hours spent in organized activities and level of performance on a standardized achievement test, controlling for students' background and alternative afterschool arrangements. Furthermore, although the achievement test scores of those 9 youth ( $2 \%$ of the sample) who spent more than 20 hours/week in organized activities was only modestly above average, their scores were approximately one-quarter of a standard deviation above the achievement of students not participating in any organized activities.

Second, Luthar et al. (2006) evaluated facets of the over-scheduling hypothesis in a cross-sectional study of 314 primarily White, 8th grade students residing in an affluent New England suburban township (median family income $=\$ 125,381$ ). Students reported the number of weekly hours spent in organized activities (i.e., sports, arts, academic activities [e.g., math club], and civic activities [e.g., church, volunteering]). This information was then related to the students' reports of their parents' criticism and expectations, their parents' emphasis on personal character vs. achievements, the frequency of having dinner with parents, their own psychological distress (i.e., Children's Depression Inventory, Revised Children's Manifest Anxiety Scale), school grades, and involvement in delinquency and substance use.

For these affluent adolescents, results from Luthar et al. were as follows: (1) The average number of hours/ week spent in organized activities was 7.5 for girls and 7.9 for boys. Sports consumed the most weekly hours and academic activities the least; (2) For boys, time spent in sports and arts activities was significantly associated with better school grades and classroom competence whereas time spent in academic activities was negatively related to school grades. The association with classroom competence was linear and the association with school grades was curvilinear such that boys with very low activity participation showed particularly low school grades compared to boys with medium or high levels of participation; (3) For girls, time spent in academic activities was associated with significantly higher self-reported delinquency and substance use, while time spent in civic activities predicted lower internalizing symptoms (i.e., depression and anxiety). These associations were linear with the exception of substance use where girls with very high amounts of academic activity involvement reported particularly high substance use relative to girls with a low or moderate amount involvement; (4) Perception of their parents' attitudes toward academic achievement, rather than the number of hours in organized activities, predicted the girls' psychosocial distress and antisocial behaviors; (5) Finally, poor adjustment was particularly evident for a very small subgroup of girls who perceived their parents as highly critical and achievement oriented and who also spent an extreme amount of time in academic activities (1.74 SD above the mean). This last finding is the only evidence in this study for the over-scheduling hypothesis and it is only true for that subset of girls whose parents are also overly critical and demanding.

Studies relying on reports of the number of activities or of the presence or absence of participation in specific organized activities provide similar results. For example, in an analysis of 4,757 adolescents from National Educa- 
tion Longitudinal Study of 1988 (NELS:88), Marsh and KIeitman (2003) examined long-term associations between participation in athletic activities and youth adjustment. The total number of athletic activities (intramural and extramural) that youth participated in during Grades 10 and 12 were considered in relation to 20 indicators of adjustment at Grade 12 (e.g., standardized achievement test scores, self-esteem, educational aspirations, lack of substance use) or two years postsecondary school (e.g., employment, university attendance, occupational aspirations). Analyses controlled for both for the students' prior adjustment on the outcomes and their sociodemographic characteristics during Grades 8 and 10. Sixty-two percent $(13 / 21)$ of the outcomes were significantly and positively associated with athletic participation (i.e., as the number of athletic activities that youth participated in increased, indicators of their well-being improved). Thus, this study provides no support for the over-scheduling hypothesis with respect athletic activities and substantial support for the positive youth development hypothesis.

Marsh (2002), in a sample of 4,422 adolescents from the High School and Beyond study, documented a significant, positive, linear association between the total number of extracurricular activities students participated in as sophomores and seniors for $77 \%(17 / 22)$ of socialacademic outcomes considered. The outcomes included self-concept, GPA, parent involvement and aspirations, college attendance, and occupational aspirations, and the analyses controlled for background factors (SES, race, gender, school size, prior educational experiences) and prior measures of the outcomes. Marsh also documented a significant quadratic effect for $68 \%$ (15 of 22) of these outcomes; however, in every case, the linear component was more strongly related to the outcomes than was the quadratic term. The fact that linear and quadratic terms were usually both significant suggests that, at high amounts of activity participation, the associated benefits leveled off. Depending on the outcome considered, Marsh found that the curve reached asymptote when the number of activities exceeded .67-4.97 SD above the mean. For this extreme subgroup of youth, Marsh did not indicate whether any of the outcomes involving a significant quadratic effect pointed to a decline in their adjustment that fell below the adjustment of youth who did not participate in extracur- ricular activities.

Using data from the Michigan Study of Adolescent Life Transition (MSALT — a longitudinal community based study of public school students in Southeastern Michigan begun in 1984), Eccles and colleagues examined the relation of amount of organized activity participation at Grade 10 with several indicators of adjustment at Grades 10, 11, and 12, and post-secondary school. Measures of adjustment included: alcohol and drug use, skipping school, school belonging, depressed mood, social isolation, self-esteem, assessment test performance, GPA, college enrollment, and job characteristics (Barber, Eccles \& Stone, 2001; Eccles \& Barber, 1999; Eccles et al., 2003). The MSALT sample is primarily White working and middle-class families. However, tests for racial differences yielded no evidence of a difference between Black and White adolescents in the relations between activity participation and indicators of youth development. Looking just at the number of activities, very few of the MSALT youth were in involved in more than 2 activities simultaneously. The majority participated in at least one activity, with the average being a little more than two in the past year. Girls and adolescents with college-educated mothers participated in the most activities. Controlling for functioning at Grade 10, mothers' education, and performance on a standardized test of math and verbal skills, those who participated in at least one organized activity showed either more improvement or less decline over time than non-participants in school achievement (GPA, high school completion, college attendance and completion), feelings of school belonging, and self-esteem. In addition, involvement in volunteer activities and faith-based activity programs predicted lowered rates of alcohol and drug use over time. Interestingly, high school sport participation also predicted higher income and better jobs at age 25 .

Most importantly for this report, with the exception of sports, they found no evidence of declines in the benefits of participation as adolescents participated in more activities. Other than sports, there was a linear increase on the indicators of positive functioning with increasing numbers and breadth of activities. The educational benefits for participating in sports leveled off following participation in two competitive team sports. In addition, athletes reported drinking more alcohol in high school (this effect was no longer evident in the post-high school waves) than 
non-athletes. Because this one problematic association was not reflected in either drug use or cigarette smoking-both of which were less frequent among athletes than non-athletes-it is likely that the increased levels of drinking reflected the peer culture of athletes in American high schools at the time of this study.

Other studies examining the amount of activity participation over the high school years also suggest long-term benefits of participation, including educational success and college attendance. For instance, an analysis of the NELS:88 dataset showed that the consistency of participation in extracurricular activities across Grades 8, 10 , and 12 was positively linked to college attendance and civic involvement during young adulthood (Zaff, Moore, Papillo, \& Williams, 2003). This held after controlling for individual, family, peer, and school-level variables. Similarly, Mahoney, Cairns, and Farmer (2003) used data from the Carolina Longitudinal Study (CLS) to trichomize the consistency of extracurricular activity participation (i.e., none, 1 year, 2 years) during both early adolescence (Grades 7 and 8) and middle adolescence (Grades 9-10). After modeling economic and interpersonal factors, consistency of participation at both age periods was positively associated with aspirations for the future during late adolescence and educational attainment-including college attendance-during young adulthood. Moreover, other findings from the CLS show that the extent of participation over time in organized activities predicts markedly lower rates of school dropout and criminal offending for youth with patterns of economic and psychosocial risks during early adolescence (Mahoney, 2000; Mahoney \& Cairns, 1997).

In sum, the existing studies that have considered the amount of organized activity participation in relation youth adjustment provide no direct support that youth are over-scheduled in organized activities. These same studies do provide substantial evidence in support of the positive youth development perspective. Across a wide range of indicators, youth who participate in organized activities show more healthy functioning than those who do not (e.g., academic achievement, self-esteem, substance use and antisocial behaviors, school belonging, civic involvement, educational/career aspirations, high school completion, and post-secondary educational attainment and job quality). This holds for studies that were cross-sectional or longitudinal and that controlled for demographic factors and/or youth's prior adjustment, whether the research sample was small and regionally based or large scale, the historical timeframe when data were collected, or whether the studies measured organized activity participation in terms of weekly hours or the total number of activities that youth participated in at one time. In many cases, indicators of well-being were found to increase in a linear fashion as the number of organized activities or hours of participation increased. However, some studies (e.g., Cooper et al., 1999; Marsh, 2002) found that indicators of well-being follow a curvilinear pattern suggesting that the benefits may level off or decline at very high amounts of participation. To gain a better understanding of these patterns - when they occur and whether, as the amount of activity participation increases, they imply that youth's adjustment increases in a positive and linear fashion, levels off, declines marginally, or declines to a level that implies risk-we now consider the time-based categories of activity participation from the PSID-CDS.

The Child Development Supplement to the Panel Study of Income Dynamics. Returning to the time-based categories of organized activity participation from the PSID-CDS, we investigated the adjusted mean levels of well-being for White and Black adolescents (ages 12-18) within each time category on two sets of indicators pertinent to the over-scheduling hypothesis: indicators related to the youth's own adjustment and indicators related to their relationships with their parents. In Figures 4-7, we highlight representative findings from the complete list of outcomes described in Appendix D. These analyses are cross-sectional and control for gender, parent education, family income, and family structure (see Appendix E for the complete table of analyses).

Our discussion of the findings focuses on the linear and quadratic trends in youth well-being associated with increasing amounts of time spent in organized activities and, where relevant, on a direct comparison between youth who spent 20 or more hours/week participating and those who did not spend any time in organized activities. However, comparisons between other time categories can be made through examination of adjusted mean level differences and standard errors reported in the rows of Appendix E.

The patterns of results for reading achievement are shown in Figure 4. For White youth, the quadratic trend was significant reflecting a tendency for achievement to increase with activity participation up to 19:59 hours/week, followed by a decline in achievement for those participating 20 or more hours/week. However, the decline did not imply academic risk as the reading achievement difference between Whites who did not participate in organized activities and those who participated 20 or 


\section{The Tip of an Iceberg?}

\section{Reed W. Larson, University of Illinois, Urbana-Champaign*}

Organized activities and youth programs are important both as an influential context in many young people's lives and as a natural laboratory for understanding developmental processes in late childhood and adolescence. Existing research indicates significant longitudinal relationships between program participation and the types of outcome variables that we know how to measure, such as self-esteem, school achievement, and problem behavior. But we need to look beyond these markers to the more fundamental—and difficult to study—social and emotional developmental change processes that programs themselves see as their central mission, such as fostering initiative, interpersonal competencies, character, and connections to adult worlds (Eccles \& Gootman, 2002; Roth \& Brooks-Gunn, 2003). By understanding these processes — and what programs do to facilitate them-researchers can contribute to improvements in practice and programming, and also gain more generalizable knowledge about diverse forms of positive development.

Paraphrasing Herbert Simon, one good place to begin researching psychological processes is with accounts from the people experiencing them. Verbal accounts are a promising window for looking at adolescents' development because an increased segment of teenagers' cognitive development is thought to involve conscious agency (Kuhn, 2006; Lerner, 2002). To obtain this kind of initial view, we have been obtaining teenagers' ongoing accounts of their experiences in high-quality programs, coupled with accounts from the adult leaders and from site observations. Through methodical analyses of these qualitative data, we are formulating preliminary "grounded theory" on the processes associated with different types of development, including:

Initiative. In many programs, youth work on projects, such as planning an event, preparing a performance, or conducting a service activity. In our analyses of two programs, youth's reports suggested a developmental process in which they developed initiative through engagement with the challenges of these projects. Through encountering and addressing challenges, they progressed from learning basics of organizing their time and effort to developing more advanced skills for strategic and contingency thinking (Larson \& Hansen, 2005).

Teamwork. In many programs these projects are collaborative, which creates demand conditions for youth to accommodate to each other's viewpoints and learn to coordinate joint actions. Convergent data from youth, leaders, and observations suggest developmental processes in which collaborating youth build trust through quid pro quo exchanges, learn to adapt to and benefit from each others' perspectives, and construct collaborative norms (Larson, in press).

Emotional development. Although some educators are trying to find ways to teach "emotional intelligence” in schools, it is possible that the "hot" positive and negative emotions that occur in youth programs provide more optimal opportunities for this learning. Our analyses of teens' experiences in a theater program suggested processes through which experiencing and dealing with emotions in a supportive context facilitated youth's conscious development of strategies for managing emotions in self, others, and groups (Larson \& Brown, 2006).

Motivation. Acquiring motivation is a huge issue in adolescence-part of the reason why parents want their otherwise bored and undirected teens in organized programs. Our analyses of one program suggested a sequence through which participants developed a capacity to enjoy work through formation of personal connections to program activities and goals (Pearce \& Larson, 2006).

Family autonomy. Research has shown that an important developmental task for adolescents is not breaking away from parents, but developing increased behavioral and emotional autonomy with continued family connection. Our research suggests that programs often provide a venue through which teens receive support and recognition from family for independent actions, which in turn leads to their gaining greater trust and autonomy within adolescent-parent relationships (Larson, Pearce, Sullivan \& Jarrett, in press).

These preliminary models of change processes, I want to emphasize, are derived from methods of discovery research. From a scientific viewpoint they do not carry the weight of quantitative hypothesis-testing studies. More research is needed. It is notable, however, that in a large survey, high school students reported these types of developmental experiences more frequently in youth programs than in school (Larson, Hansen, \& Moneta, 2006). But the bigger point is that current longitudinal findings on the benefits of organized activities and youth program may represent only the tip of a much larger iceberg of social and emotional developmental processes that occur in these contexts.

*This research was funded with grants from the William T. Grant Foundation. Copies of articles from the research can be accessed at: http://web.aces.uiuc.edu/youthdev/. 
References

Eccles, J. \& Gootman, J. (2002). Community programs to promote youth development. Washington, DC: National Research Council, National Academy Press.

Kuhn, D. (2006) Do cognitive changes accompany developments in the adolescent brain? Perspectives on Psychological Science, $1,59-67$.

Larson, R. (in press). From "I" to "We": Development of the capacity for teamwork in youth programs. R. Lerner \& R. Silberstein (Eds.). Approaches to positive youth development. Thousand Oaks, CA: Sage.

Larson, R. W. \& Brown, J. R. (2006). Emotional development in adolescence: What can be learned from a high school theater program. Manuscript submitted for publication.

Larson, R. \& Hansen, D. (2005).The development of strategic thinking: Learning to impact human systems in a youth activism program. Human Development, 48, 327-349.

Larson, R. W., Hansen, D., \& Moneta, G. (2006). Differing profiles of developmental experiences across types of organized youth activities. Developmental Psychology, 42(5).

Larson, R. W., Pearce, N., Sullivan, P., \& Jarrett, R. L. (in press). Participation in youth programs as a catalyst for negotiation of family autonomy with connection. Journal of Youth and Adolescence.

Lerner, R. L. (2002). Concepts and theories of human development ( $3^{\text {rd }}$ Ed.). Mahwah, NJ: Lawrence Erlbaum Associates.

Pearce, N. \& Larson, R. (2006). The process of motivational change in a civic activism organization. Applied Developmental Science, 10, 121-131.

Roth, J. \& Brooks-Gunn, J. (2003). Youth development programs: Risk, prevention, and policy. Journal of Adolescent Health, 32, 170-182.

more hours/week was not significant. Among Black youth, linear and quadratic trends were significant and indicate that reading achievement increased with participation in organized activities through the 10:00-14:59 hours/week category and then declined somewhat. However, the reading achievement for Black youth who participated in organized activities was always higher than those who did not participate; the difference between non-participants and those who participated 20 or more hours/week was significant $(p<.01)$.

Results for adolescent psychological adjustment are presented in Figure 5. For emotional well-being, linear and quadratic trends were significant for White youth reflecting an increase to asymptote between 5:00-9:59 hours/week of participation. For Black youth, the linear trend was significant indicating that emotional well-being became more positive as weekly hours in organized activities increased. For global self esteem, both the linear and quadratic trends were again significant for White youth indicative of an increase in self-esteem to asymptote between 5:00-9:59 hours/week of activity participation. In contrast, only the quadratic trend was significant for Black youth. This reflects an increase in self-esteem for Black youth who participated in organized activities up to 19:95 hours/week, followed by a decline for those who spent 20 or more hours/week participated. The self-esteem of Black youth who spent 20 or more hours/week in organized activities was significantly lower than their counterparts who did not participate in organized activities $(p<.05)$.

The findings for substance use are presented in Figure 6. For cigarette use, the linear trend was significant for Whites indicating a decline as weekly/hours spent in organized activities increased. For Blacks, the linear and quadratic trends were significant and point to a decline in cigarette use that reached asymptote between 5:00-9:95 hours/week of participation. For alcohol use, the results were similar for White and Black youth: the significant linear and quadratic trends reflect a decline in alcohol use for youth who participated in organized activities up to 14:59 hours/week followed by an increase in alcohol use for those who spent 15 or more hours/week participating. However, even those White and Black youth who participated 20 or more hours/week showed significantly lower alcohol use compared to those who did not participate ( $p$ $<.05)$.

Finally, concerning the measures of parent-adolescent relationships shown in Figure 7, linear and quadratic trends were significant for both White and Black youth. 


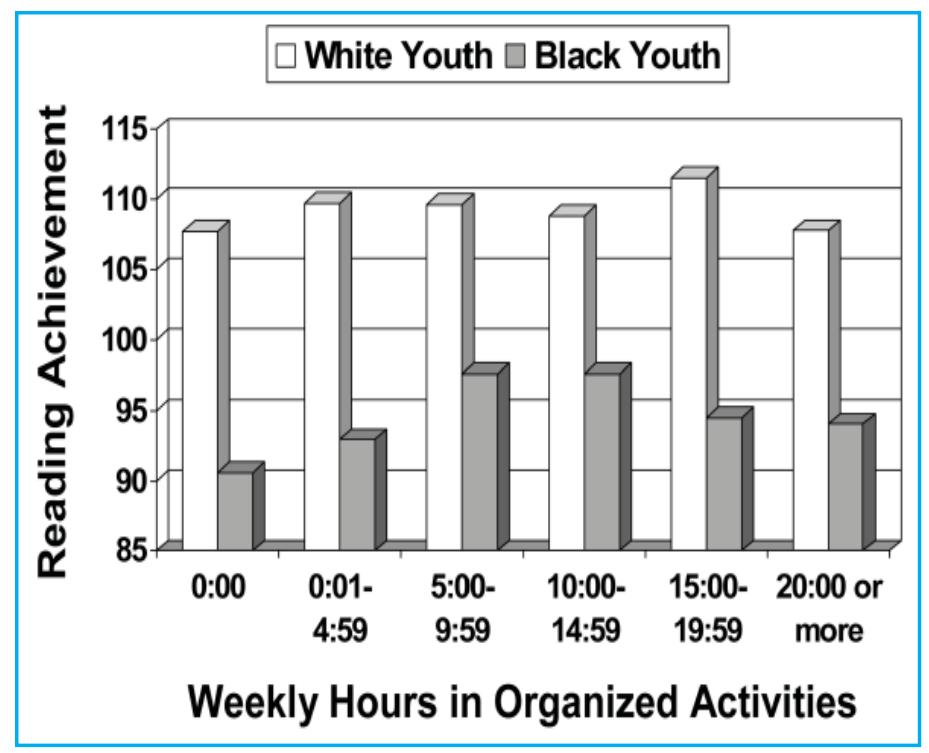

Figure 4. Reading achievement for White and Black youth (ages 12-18) by time spent on organized activities.

Organized activity participation was related to a significant increase in the frequency of eating meals together with their parents. For White youth, this increased to asymptote between 5:00-9:59 hours of weekly participation; for Black youth, the linear trend was strongest, reflecting an increase that continued through 20 or more of weekly activity participation. This pattern is similar for the frequency of parent-adolescent discussions among White youth though the asymptote occurs sooner and reflects the fact participants as a group had more frequent discussions with their parents compared to non-participants. In contrast, for Black youth, while discussions with parents tended to be as, or more, frequent up to 19:59 hours/week of participation, the frequency of these discussions declined for those who spent 20 or more hours/week participating in organized activities. Consistent with the over-scheduling hypothesis, spending 20 or more hours/week in organized activities was associated with less frequent discussions with parents for Black youth relative to non-participants $(p<.001)$.

\section{Discussion}

In this paper, we have explored two perspectives regarding the relation of organized activity participation and development: the positive youth development perspective and the over-scheduling perspective. On the one hand, advocates of positive youth development have argued that participation in organized activities facilitate optimal development and therefore policymakers should provide more opportunities for American youth to be in-

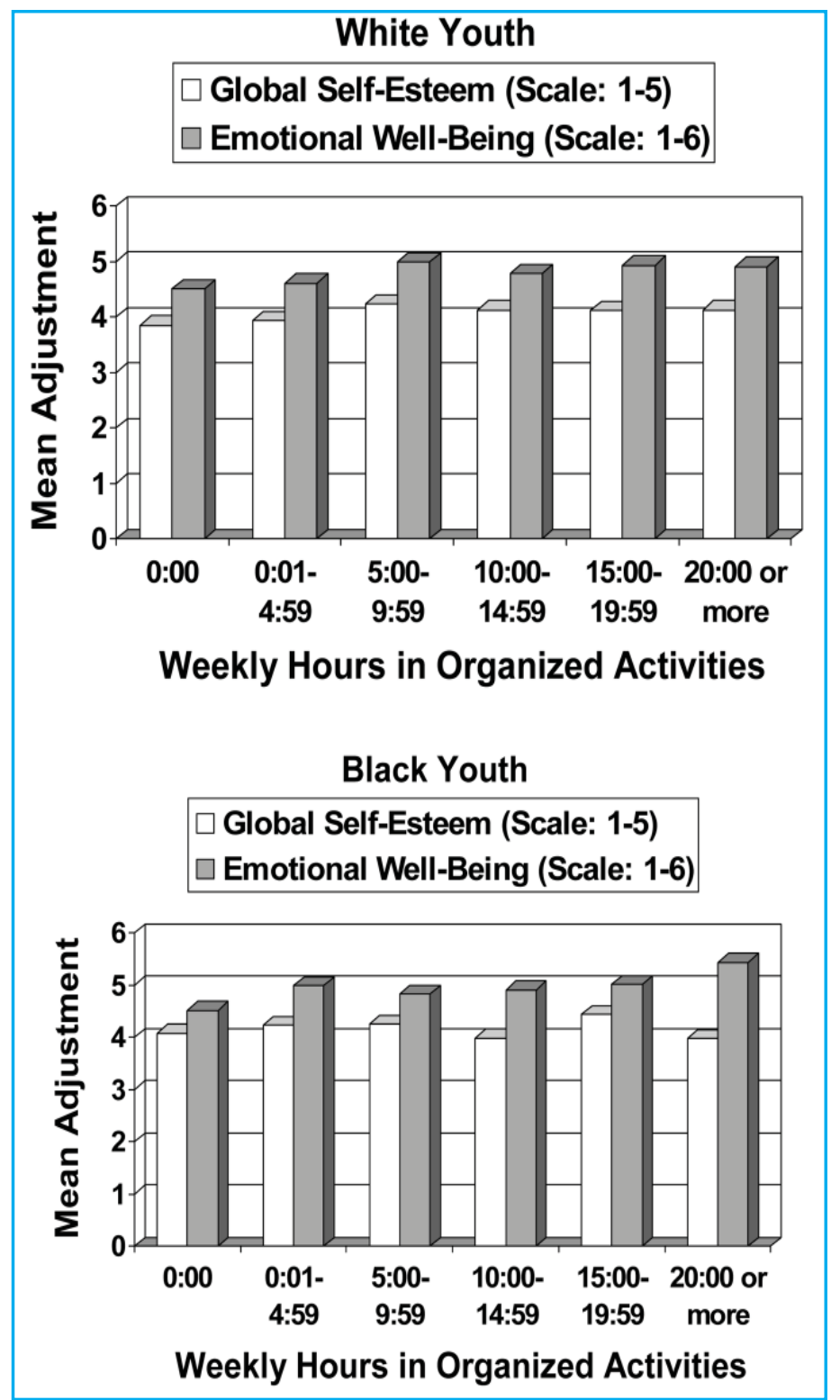

Figure 5. Psychological adjustment for White and Black youth (ages 12-18) by time spent on organized activities.

volved in such activities (c.f., National Research Council and Institute of Medicine, 2002). On the other hand, some writers have suggested that participating in organized activities has become excessive for some young people, owing, in part, to achievement pressures from parents and other adults (e.g., Gilbert, 1999; Rosenfeld \& Wise, 2000). These authors maintain that external pressures, along with the activity-related time commitment, can contribute to poor psychosocial adjustment for youth and to undermine relationships with parents. If this is the case, then attention 


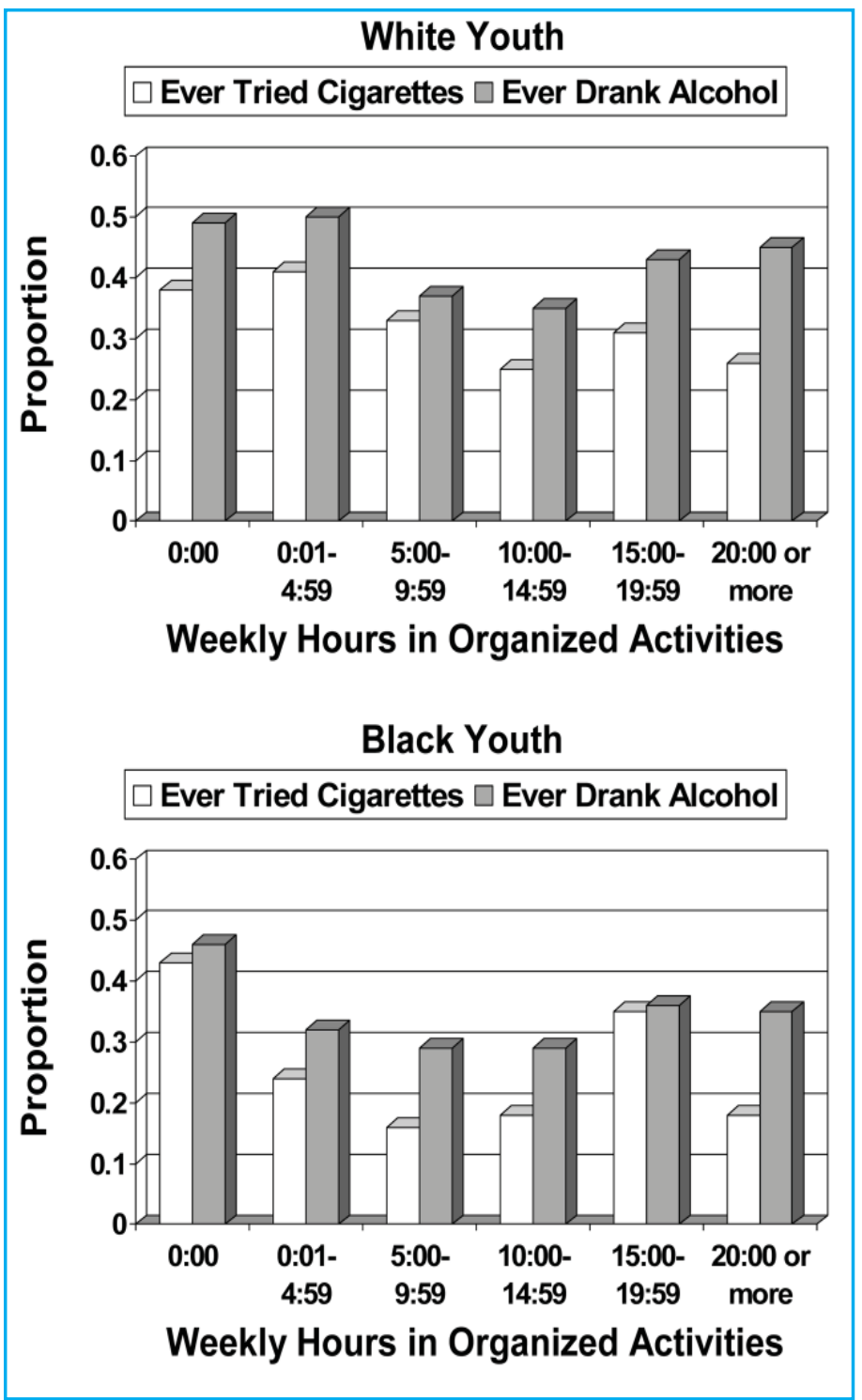

Figure 6. Substance use outcomes for White and Black youth (ages 12-18) by time spent on organized activities.

from scientists, practitioners, and policymakers are warranted. Our goal was to bring scientific evidence to bear on both of these perspectives.

The available research base provides far more support for the positive youth perspective than for the over-scheduling perspective. To begin, the belief that organized activity participation is often motivated by parental pressure to achieve or attain long-term educational and career goals is not supported by the limited available empirical data. Overwhelmingly, the primary reasons adolescents give for participating in organized activities are intrinsic and focus on the here and now. This holds for the few studies that

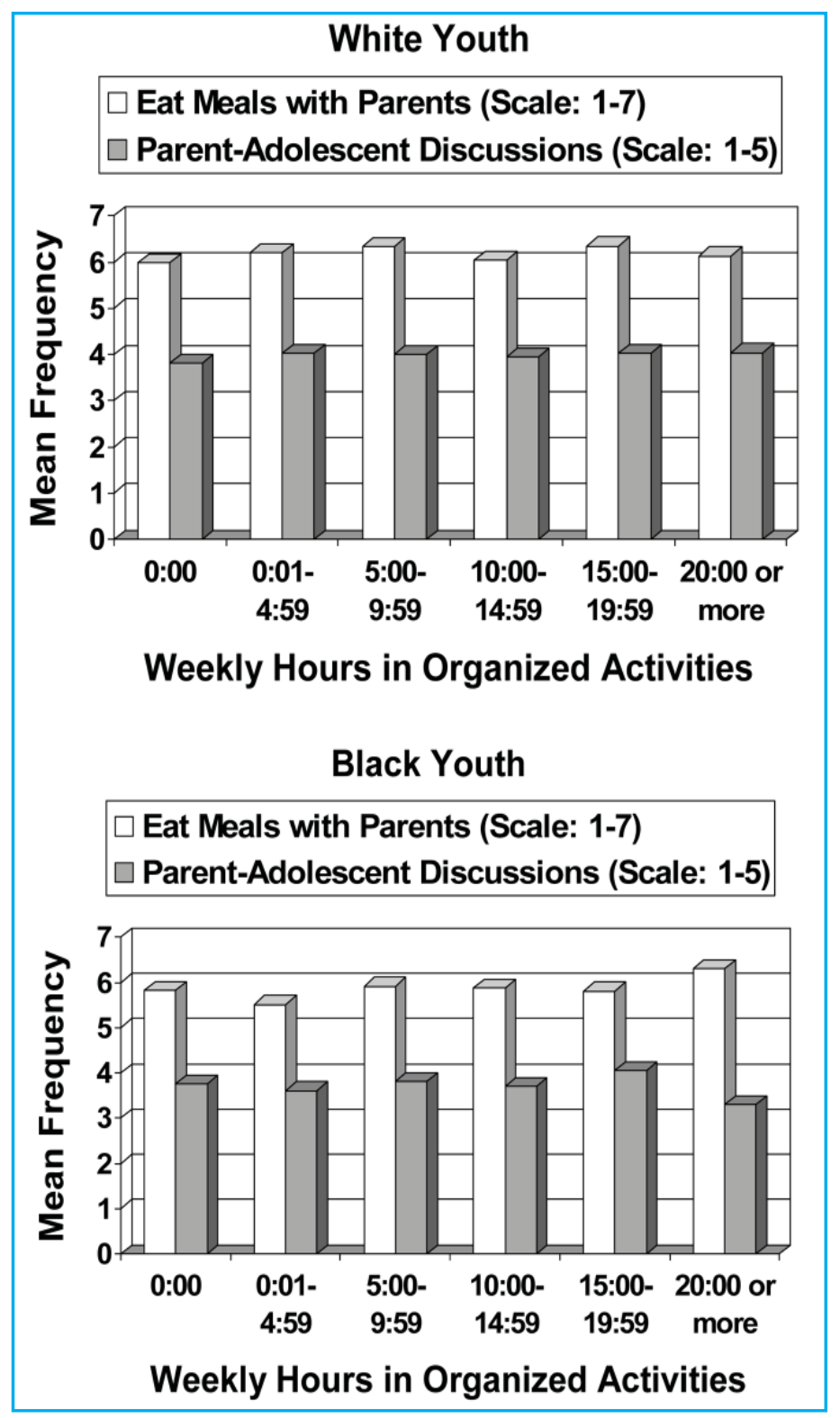

Figure 7. Parent-adolescent outcomes for White and Black youth (ages 12-18) by time spent on organized activities.

sampled affluent and suburban youth with relatively high levels of involvement in organized activities (e.g., Csikszentmihalyi et al., 1993; Luthar et al., 2006). However, there is a paucity of information on whether the reasons for participation vary according to either the amount or type of organized activity participation, or the age and other demographic characteristics of the participants and their families. We need to know much more about the relation between the participants' and their parents' motivations, goals, values, and expectations and the choices children/adolescents make about their discretionary time, 


\section{Over-Scheduling Versus Other Stressors: Challenges of High Socioeconomic Status Families Suniya S. Luthar, Columbia University's Teachers College}

In their review article, Mahoney, Harris, and Eccles illuminate the likely fallacy within a widely-held belief-that overscheduling is responsible for the distress and substance use seen in a surprisingly high proportion of youth of highly educated, well-to-do parents. Suggestions to this effect have been put forth by clinicians as well as developmental scientists (Luthar \& Sexton, 2005) and have been widely disseminated by the media.

There may in fact be much distress among youth in upwardly mobile communities, but the causes are still unclear. Family pressures are often mentioned and, in fact, as many as two-thirds of affluent youth have reported feeling their parents were overly critical and/or emotionally distant. Moreover, these children showed vulnerability in diverse adjustment domains two years later (Latendresse \& Luthar, 2006).

To pinpoint parents as the sole or even major source of problems, however, is misguided and wrong. For decades, people in poverty have been stereotyped as being lazy, shiftless, and irresponsible (Lott, 2002), and in parallel fashion, the well-to-do are stereotyped as arrogant, entitled, and selfish (Luthar, 2005). Over the last century, research has helped uncover what it is, about life in poverty that constrains parents in terms of well-being and their parenting (Conger et al., 2002; Luthar, 1999). We need similar research for parents at the other socioeconomic extreme.

Perhaps more so than the children, it is the parents who are overextended, with ongoing conflicts regarding their life roles. On the one hand is the deep-seated desire to be the best possible parents for their children. On the other hand can be powerful draws from work; these are often gifted individuals, passionate about careers that bring feelings of self-efficacy as well as support networks (Csikszentmihalyi, 1999). Prevalent social and economic policies preclude effectiveness at raising families while simultaneously pursuing demanding careers: Job-sharing and flexible hours are not an option for CEOs or university presidents. Policies that force such difficult life choices warrant serious examination.

Also potentially implicated are pressures to provide “sufficient” financial support. Economists note that as people’s incomes and, therefore, the value of their time increases, they feel increasingly compelled to devote time toward making money. Admittedly, this could reflect some parents' selfish acquisitiveness. Equally, however, it could—given the materialistic culture of contemporary America-reflect their guilt at voluntarily choosing not to work hard to acquire all one can to provide for the next generation.

It must be emphasized that stresses within families—-whatever the processes—can explain but a fraction of the problem; the peer group also clearly plays a part (Harris, 1998). Research communities have demonstrated affluent peers' approval for adolescents' substance use, particularly among boys, and an inordinately high emphasis on physical attractiveness—and admiration of unkindness to others-among adolescent girls (Luthar \& Sexton, 2005). None of these are value systems conducive to good psychological health.

Social comparisons might also be implicated (Luthar, 2003). In high SES schools, a large number of students covet a handful of Ivy-league bound spots, closely watching each others' grades and accomplishments. To be in constant competition with their "friends" could constrain intimacy in relationships, besides making for feelings of shame and self-doubt.

What of the schools? In upwardly mobile communities, educators tend to encourage students to enroll in multiple advanced placement (AP) courses. Parents often complain that the schools put too much pressure on students (as school administrators lament parents' demands for evermore AP classes).

And then there is the media, with ubiquitous endorsements of the American Dream, founded on the maxim that "more is better": more money, more power, and more physical beauty are what make for ultimate happiness. Such extrinsic rewards, in turn, are seen as most expediently acquired via the most competitive schools and colleges. Little surprise, then, if today's economically privileged children were to rarely cite life goals such as seeking intellectual challenge or contributing to humankind; these are not goals touted in contemporary American culture.

From a policy perspective, it is critical to sustain attention to the nature and causes of problems of high SES youth. Many of these children, like their parents, will eventually assume positions of influence in society, and their own sense of well-being could have far-reaching ramifications. Depression vastly impairs productivity. And people who are unhappy, with a fragile sense of self, can be more acquisitive than philanthropic, focused more on gaining more for themselves rather than on contributing to the welfare of others (Diener \& Biswas-Diener, 2002).

Also critical are efforts at dissemination of relevant evidence, via books and articles comprehensible to the lay public 
(e.g., Kasser, 2002; Levine, 2006; Myers, 2000). While obviously not panaceas, such dissemination efforts could begin to sensitize caregivers to risks in the context of affluence-risks that they (like we, in developmental science) may have been only faintly aware of in the past.

Such dissemination efforts should target not just parents but also communities, to promote collaborative initiatives such as those providing after-school care. Until there are more flexible policies in the American workforce, extant community resources must be brought to bear in promoting positive youth development. Encouragingly, some communities are beginning such efforts, as seen in the town of Westport, Connecticut. With research evidence of various problems among youth lacking adult after-school supervision, local stakeholders collaboratively launched an after-school program for middle school students. The program was designed by the adults with input from the students and reportedly was well utilized.

In conclusion, the distress of high SES youth cannot be attributed mainly to over-scheduling - extracurricular activities are generally salutary for them as they are for most youth. Some families may indeed feel compelled to do too much. However, peers, schools, and the broader sociocultural context are also clearly implicated, as pioneers in child development have long emphasized (Bronfenbrenner, 1986; Sameroff \& Chandler, 1975; Zigler, Lamb, \& Child, 1982). The American cultural context routinely lauds material success as the pathway to happiness (and Ivy League educations as a route to this success), propelling all to achieve the most they can with their capabilities and talents. Most seriously implicated are work policies in America, which render it near-impossible for parents to maintain satisfying, high-impact careers along with close, connected relationships with their families. Without serious re-examination of these national policies, there is little hope of reducing the pressures and distress among high SES youth. There will be continued erosion of youngsters' potential, diminishing their capacities to maximize the well-being of not only their own families of tomorrow, but also, eventually, of society at large.

\section{References}

Bronfenbrenner, U. (1986). Ecology of the family as a context for human development: Research perspectives. Developmental Psychology, 22, 723-742.

Conger, R. D., Wallace, L. E., Sun, Y., Simons, R. L., McLoyd, V. C., \& Brody, G. H. (2002). Economic pressure in African American families: A replication and extension fo the family stress model. Developmental Psychology, 38, 179-193.

Csikszentmihalyi, M. (1999). If we are so rich, why aren’t we happy? American Psychologist, 54, 821-827.

Diener, E., \& Biswas-Diener, R. (2002). Will money increase subjective well-being? Social Indicators Research, 57, 119169.

Harris, J. R. (1998). The nurture assumption: Why children turn out the way they do. New York: Touchstone.

Kasser, T. (2002). The High Price of Materialism. Cambridge, MA: MIT Press.

Latendresse, S. J., \& Luthar, S. S. (2006). Perceptions of Parenting among Affluent Youth: Antecedents of Middle School Adjustment Trajectories. Manuscript submitted.

Levine, M. (2006). The price of privilege: How parental pressure and material advantage are creating a generation of disconnected and deeply unhappy kids. New York: HarperCollins.

Lott, B. (2002). Cognitive and behavioral distancing from the poor. American Psychologist, 57, 100-110.

Luthar, S. S. (1999). Poverty and children's adjustment. Thousand Oaks, CA: Sage.

Luthar, S.S. (2003). The culture of affluence: Psychological costs of material wealth. Child Development, 74, 1581-1593.

Luthar, S. S., \& Latendresse, S. J. (2005). Children of the affluent: Challenges to well-being. Current Directions in Psychological Science,14(1), 49-53.

Luthar, S. S., \& Sexton, C. (2005). The high price of affluence. In R. V. Kail (Ed.), Advances in Child Development, 32, 126162. San Diego, CA: Academic Press.

Myers, D.G. (2000). The American paradox: Spiritual hunger in an age of plenty. New Haven, CT: Yale University Press.

Sameroff, A. J., \& Chandler, M. J. (1975). Reproductive risk and the continuum of caretaking casualty. In F. D. Horowitz, M. Hetherington, S. Scarr-Salapatek, \& G. Siegel (Eds.), Review of child development research (Vol. 43, pp. 187-244). Chicago: University of Chicago.

Zigler, E. F., Lamb, M. E., \& Child, I. L. (1982). Socialization and personality development (pp. 97-119). New York: Oxford University Press. 
in general, and the amount of time they devote to various types of organized activities, more specifically (Eccles, Wigfield, \& Schiefele, 1998; Fredricks \& Eccles, 2005; Jacobs et al., 2005).

On the basis of time alone, very few American youth devote enough time to organized activities to be classified as "over-scheduled." For example, youth in the PSID-CDS - the only nationally representative sample of American youth with time use data - averaged about 5 hours/week in organized activities on any given week during the school year; furthermore, roughly $40 \%$ of the PSID-CDS youth did not participate in any organized activities and those who did typically spent fewer than 10 hours/week doing so. Comparable estimates emerged in the other studies we reviewed. These findings suggest that organized activities do not dominate the vast majority of American youth's free time. Instead, the majority of their time is consumed by other leisure pursuits such as watching television, educational activities, playing games, hanging out, and personal care (c.f., Larson \& Verma, 1999). In other words, given the considerable amount of discretion time typically available to young Americans, most appear able to balance their organized activity participation effectively with school-related tasks, family time, informal socializing with peers, and relaxing. Nevertheless, there was evidence in some of the studies reviewed (e.g., Cooper et al., 1999; Marsh, 1992; Marsh \& Kleitman, 2003), as well as in the PSID-CDS analyses reported in this paper, of a subgroup of youth (3\% of children and $6 \%$ of adolescents) who spend a very high amount of time (20 or more hours/week) participating in organized activities. Are these youth poorly adjusted as a result of their high levels of participation in organized activities? By and large the evidence suggests not. Like their slightly less involved peers, they appear to be functioning better than non-involved youth. We discuss this more later.

In general, youth who participate in organized activities score better on a variety of indicators of healthy development than youth who do not participate. For example, those PSID-CDS youth who participated in organized activities for fewer than 20 hours/week scored better than the youth who did not participate in any activities on all of the indicators of well-being. This finding was true for all of the studies we reviewed and is consistent with the evidence summarized by Eccles and Gootman in their 2002 report for the National Research Council and the Institute of Medicine on the Community Based Programs for Youth. Thus, reliable support for the benefits of participation in organized activities emerged across studies and these benefits, by and large, become stronger with increased participation. Although the scheduling of responsibilities surrounding organized activities can sometimes be challenging for families (Lareau, 2003), the associated benefits of participation are apparent nonetheless.

What about those youth who participate a great deal? Once again the findings across studies provide very limited support for the hypothesis that too much participation can be harmful. Many of the existing studies find a linear increase in the psychological, social, and academic well-being of youth as the number of organized activities or weekly hours of participation increases (e.g., Eccles \& Stone, 2001; Eccles \& Barber, 1999; Eccles et al., 2003, Marsh \& Kleitman, 2002; Mahoney et al., 2003). Other studies report a curvilinear trend such that the well-being of youth with very extreme levels of involvement may level off or decline somewhat; however, these studies do not provide evidence that even very high amounts participation confers risk (Cooper et al., 1999; Marsh, 2002). The findings regarding the well-being of the extreme $6 \%$ of PSID-CDS youth who participated in organized activities 20 or more hours/week are generally consistent with these other studies. Clearly, the White youth who participated for 20 or more hours/week were better off than those White youth who did not participate in any activities on all but one of the indicators assessed: They reported higher levels of self-esteem and psychological and emotional well-being; lower alcohol, marijuana, and cigarette use; and ate meals with their parents and engaged in discussion with them more frequently. The only potentially negative finding for these White youth was that shared activities with their parents occurred less frequently. The findings for PSIDCDS Black youth were less consistent. On the one hand, the Black youth who participated in organized activities for 20 or more hours/week had higher reading achievement; reported higher emotional well-being; lower alcohol, marijuana, and cigarette use; and ate meals together with their parents more frequently than their Black peers who did not participate in any organized activities. On the 
other hand, these Black youth also reported less frequent parent-adolescent discussions and lower self-esteem and psychological well-being than their Black peers who did not participate.

The reasons for few the negative findings from the PSID-CDS and other studies need to be investigated before policy implications can be drawn. They may or may not be indicators of a negative impact of over-scheduling on adolescent development. For example, in the PSID-CDS, the fact that older adolescents may spend somewhat less time with their parents is not necessarily an indication of problems. Instead it could reflect normative increases in autonomy among competent young people. Thus, more needs to be known about the causes and consequences of this association before drawing any conclusions about whether they imply a developmental risk in these adolescents' lives. Likewise, the finding by Luthar et al. (2006) that a very small group of early adolescent females from affluent families demonstrated high internalizing symptoms and poor school adjustment when they were both highly involved in academic activities and perceived their parents as critical and overly achievement-oriented requires additional study before conclusions concerning over-scheduling can be made. One possibility is that a high amount of activity participation is associated with adjustment problems primarily for youth who do not receive positive support from their parents. This is consistent with research showing that activityrelated support and encouragement from parents plays an important role in youths' enrollment and continued participation in organized activities (Fletcher et al., 2000; Simpkins et al., 2005). Parent-adolescent relations may also help to explain why the PSID-CDS findings showed that a very high amount of organized activity participation was associated with lower self-esteem and psychological well-being for Black adolescents; these same youth also reported a low frequency of parent-adolescent discussions. However, other studies have found have found a positive, linear association between the amount of organized activity participation and self-esteem during adolescence (e.g., Barber et al., 2001; Marsh \& Kleitman, 2003). Thus, to understand better what underlies these associations, process-oriented longitudinal research is needed. Moreover, given the many associated benefits of participation for other areas of their adjustment, follow-up studies are re- quired to assess whether these highly involved adolescents are at risk for poor adjustment in the long term.

Despite these few possible risks of very high levels of activity participation, we do not believe efforts to limit adolescents' participation in organized activities are warranted for several reasons. First, across all studies reviewed, those few youth with very high levels of organized activity participation did not show negative adjustment in most of the indicators assessed and they demonstrated significantly healthier functioning than non-participants on many indicators of well-being. Furthermore, there is evidence that greater amounts of participation are positively associated with civic engagement, high school graduation, and college attendance, and are negatively related to antisocial behaviors and criminal offending (e.g., Barber et al., 2001; Cooper et al., 1999; Eccles \& Barber, 1999; Eccles et al., 2003; Mahoney, 2000; Mahoney et al., 2003; Marsh \& Kleitman, 2003; Zaff et al., 2003). Therefore, even if a causal relation exists between very high amounts of participation and some negative outcomes, it is not clear that the cumulative effect of limiting participation for this extreme subgroup would be positive or negative.

Second, none of the studies reviewed in this report focused on stability and change in the amount of organized activity participation over time. Therefore, they tell us nothing about whether the very high amounts of participation that characterizes a small subgroup of youth is stable or transient across adolescence. It is possible that some youth extend their time commitment in organized activities to a very high level for a limited time. During this time, certain indicators of well-being may decline somewhat. However, this does not imply that such youth maintain a very high level of participation across all of adolescence or that their long-term well-being is compromised as a result. To evaluate whether this is the case, longitudinal data measuring adolescents' time use and well-being over time are required.

Third, the existing research concerning amount of organized activity participation and youth adjustment has only begun to examine whether findings vary according to individual characteristics or features of the activity context. For example, studies of high-risk youth show that a lack of organized activity participation predicts poor academic adjustment and high rates of obesity, school dropout, and 


\section{Next Steps: Considering Patterns of Participation \\ Jodie L. Roth, National Center for Children and Families Teachers College, Columbia University}

The impression that today's parents are raising a generation of over-scheduled youth resonates with both the media and parents attempting to navigate the maze of work schedules, after-school activities, increased academic demands, and concerns for their children's current and future well-being. The findings presented in this Social Policy Report, however, refute such sweeping assessments of the after-school schedules of today's youth and demonstrate the public's misplaced concern about over-scheduled youth. The developmental costs of no participation in organized activities remain far more worrisome.

Yet, as the authors note, this faulty image of overextended youth persists, despite growing evidence, and acceptance, of the benefits of participation. Perhaps a shift in comparisons, moving beyond participation vs. no participation toward understanding the implications for development from participation in different types and combinations of activities, as well as activities of varying quality, can further the work begun by their research and help refocus the image. When picturing the after-school schedules of active youth, a variety of possible images exist. Whether one envisions a youth rushing to different after-school activities every afternoon, striving for the competitive edge in one activity through an elaborate schedule of lessons and practice, or attending an aftercare program, encourages different scenarios of the possible developmental consequences from participation.

These scenarios reflect the discrepant schedules among participants in organized activities; a reality not adequately captured in most of the current research. In the review of the literature my colleagues and I are conducting, we found few studies that incorporated the varying forms of participation ${ }^{1}$ (Roth \& Brooks-Gunn, 2006). Organized activities differ in both obvious and subtle ways that can contribute to their developmental influence. For example, researchers have identified more favorable associations between adolescents' participation in after-school activities and their well-being (e.g. more personal and interpersonal developmental experiences, avoidance of risky peers) among youth involved in prosocial activities such as faith-based groups and community service relative to their peers in academic clubs, sports, and performing arts (Barber, Stone, Hunt, \& Eccles, 2005; Larson, Hansen, \& Moneta, in press).

Given these differences, it is surprising how few studies explore differential associations between developmental outcomes and the type and combination, or breadth, of activities. The few that do, however, found that although youth who pursued a single activity domain fared better academically and behaviorally than youth who did not participate in any organized activity, youth who participated in a variety of activity domains showed the most consistently beneficial outcomes (Morris \& Kalil, 2006; Pedersen et al., 2005).

Measuring intensity of participation, as done in this study, captures another crucial, but often neglected, piece of information about participation - time. Relationships with adult leaders, peers, and institutions, each partially driving links between out-of-school activities and favorable developmental outcomes, take time to develop. Measures of intensity, how often youth participate, and duration, for how long, convey such information (Simpkins, Little, \& Weiss, 2004). The handful of empirical studies that include measures of duration all find positive associations between sustained participation and outcomes. For example, participants in an after-school program for two years showed greater academic improvements than one-year participants (Reisner, White, Russell, \& Birmingham, 2004). Favorable long-term associations emerged as well between continued participation in after-school activities during high school and college attendance (Mahoney, Cairns, \& Farmer, 2003; Zaff, Moore, Papillo, \& Williams, 2003).

This brief overview of the literature on comparisons of outcomes among participants with varying patterns of participation shows the benefits not only of participation, but of sustained (duration) participation in a variety of activities (breadth). Thus, it underscores the importance of participation by illustrating the benefits of more participation, in a greater variety of activities rather than less, and over a longer, rather than shorter, period of time. Future research that captures the various participation scenarios can help clarify the public's impression of the role activities play in the lives of today's youth.

${ }^{1}$ Information about this project, funded by the W.T. Grant Foundation, is available on our website, http://nccf. tc.columbia.edu/. 


\section{References}

Barber, B. L., Stone, M. R., Hunt, J. E., \& Eccles, J. S. (2005). Benefits of activity participation: The roles of identity affirmation and peer group norm sharing. In J. L. Mahoney, R. W. Larson \& J. S. Eccles (Eds.), Organized activities as contexts of development: Extracurricular activities, after-school and community programs (pp. 185-210). Mahwah, NJ: Lawrence Erlbaum Associates.

Larson, R. W., Hansen, D. M., \& Moneta, G. (in press). Differing profiles of developmental experiences across types of organized youth activities. Developmental Psychology.

Mahoney, J. L., Cairns, B. D., \& Farmer, T. W. (2003). Promoting interpersonal competence and educational success through extracurricular activity participation. Journal of Educational Psychology, 95, 409-418.

Morris, P., \& Kalil, A. (2006). Out of school time use during middle childhood in a low-income sample: Do combinations of activities affect achievement and behavior? In A. C. Huston \& M. N. Ripke (Eds.), Developmental Contexts in Middle Childhood: Bridges to Adolescence and Adulthood (pp. 237-259). New York: Cambridge University Press.

Pedersen, S., Seidman, E., Yoshikawa, H., Rivera, A. C., Allen, L., \& Aber, J. L. (2005). Contextual competence: Multiple manifestations among urban adolescents. American Journal of Community Psychology, 35(1-2), 65-82.

Reisner, E. R., White, R. N., Russell, C. A., \& Birmingham, J. (2004). Building quality, scale and effectiveness in after-school programs: Summary report of the TASC evaluation. Washington, DC: Policy Studies Associates. Available from http://www. policystudies.com

Roth, J., \& Brooks-Gunn, J. (2006). Delving deeper in the meaning of participation: Implications of variations in participation. New York: National Center for Children and Families, Teachers College, Columbia University. Available from http://nccf. tc.columbia.edu

Simpkins, S. C., Little, P. M. D., \& Weiss, H. B. (2004). Understanding and measuring attendance in out-of-school time programs (No. Number 7). Cambridge, MA: Harvard Family Research Project. Available from http://www.gse.harvard.edu/hfrp

Zaff, J. F., Moore, K. A., Papillo, A. R., \& Williams, S. (2003). Implications of extracurricular activity participation during adolescence on positive outcomes. Journal of Adolescent Research, 18(6), 599-630.

crime (e.g., Mahoney, 2000; Mahoney, Lord, \& Carryl, 2005a; 2005b; Posner \& Vandell, 1999). For these youth, even a very high amount of organized activity participation may be better than spending time in arrangements that lack adult supervision or do not provide opportunities to build competencies (e.g., Marshall, Garcia Coll, McCartney, Keefe, \& Ruh, 1997; McHale, Crouter, \& Tucker, 2001; Pettit et al., 1999). Likewise, the consequences of high amounts of participation are certain to depend on the features of the activity considered. Participation in high-quality organized activities (e.g., National Research Council and Institute of Medicine, 2002) is likely to be associated with positive youth development across the full range of hours considered in this report. In contrast, participation in activities that are poorly designed is predictive of relatively poor adjustment (e.g., Mahoney, Lord, \& Stattin, 2004; Pierce, Hamm, \& Vandell, 1999; Rosenthal \& Vandell, 1996). Thus, attention to person and program features is needed before making decisions concerning the small proportion of youth who demonstrate very high amounts of organized activity participation.

Fourth, attention to person and program features is also relevant when interpreting the somewhat small effect sizes reported in some studies reviewed in this report (e.g., Cooper et al., 1999; Marsh, 2002; Marsh \& Kleitman, 2003). For example, results from Marsh's (2002) study indicate that, across the multiple significant and positive outcomes, the well-being of youth who were highly involved in organized activities youth was, on average, $.22 S D$ (range .05-.58) above that of youth who did not participate. Results from the PSID-CDS showed that the time spent in organized activities explained an average of 8.8\% of variance in the adolescent outcomes considered (see Appendix E). Because youth typically spend much less time in organized activities than in other contexts (e.g., school and family), the associated impact of participation in any one area of adjustment should ordinarily be modest (Kane, 2004). However, in regard to the positive youth development perspective, such effects sizes are reported consistently across a broad array of outcomes and, therefore, are large enough to be of practical importance (e.g., Marsh, 2002; McCartney \& Rosenthal, 2000). In addition, research suggests that the magnitude of activity-related benefits may be greatest for: 1) youth who show stable 
participation over time; 2) those at the highest risk for poor developmental outcomes; 3) when long-term indicators of well-being are considered; and 4) when the quality of the program is high (e.g., Barber et al., 2001; Mahoney et al., 2003; National Research Council and Institute of Medicine, 2002). Thus, there are likely to be many youth for whom participating in organized activities has a very large and positive effect. Similarly, to the extent that some youth participate in low-quality organized activities, the average effect sizes reported may have been diminished. Given the positive associations identified in the PSID-CDS and the other studies reviewed, one conclusion that is possible is that we need to provide America's youth with more, rather than less, opportunities to participate in high-quality, organized activities.

Finally, we note some parallels between the findings connected to organized activity participation and those pertaining adolescent participation in the paid labor force (e.g., National Research Council and Institute of Medicine, 2003). Both become normative developmental experiences during adolescence, show variability according the family earnings and race, are viewed as a source of preparation for adult roles and responsibilities, and call attention to a small proportion of youth with very high levels of involvement - the consequences of which appear mixed. In the youth employment literature, research on working conditions and quality, reasons that motivate long hours of work, and long-term follow-ups have helped to clarify the pros/cons of young people who work extended hours. These types of studies suggest next steps for research aimed at understanding better the consequences of very high amounts of organized activity participation.

Our overall conclusion is that there is scant support for the over-scheduling hypothesis and considerable support for the positive youth development perspective. As such, we recommend that recent efforts to expand opportunities for organized activity participation should stay the course. For the vast majority of young people, participation in organized activities is positively associated with indicators of well-being. Of greater concern than the over-scheduling of youth in organized activities is the fact that many youth do not participate at all. The well-being of youth who do not participate in organized activities is reliably less positive compared to youth who do participate.

Endnotes

${ }^{1}$ We use the terms "White” and "Black” rather than "African American” and "European American” to describe racial status. The term "Black” incorporates the fact that participants were sometimes of West Indian heritage (i.e., Jamaican, Haitian) and preferred to describe themselves in this way. Because Hispanics were not included in the analyses, the term "White” encapsulates all respondents who might otherwise be referred to as "European American." ${ }^{2}$ For a detailed description of PSID-CDS weight construction see http://psidonline.isr.umich.edu/CDS/weightsdoc.html.

${ }^{3}$ Data from the PSID-CDS confirms that sports are a dominant organized activity for adolescents. For example, adolescents (ages 12-18) who participated in organized activities spent more weekly hours in sports vs. all other types of organized activities combined (3:54 vs. 2:25 for White youth; 4:11 vs. 1:50 for Black youth). However, this was not true in childhood (ages 5-11) where the weekly hours devoted to sports vs. non-sports activities was 2:21 vs. 2:22 and 1:22 vs. 2:11 for Whites and Blacks, respectively.

${ }^{4}$ In the context of evaluating the over-scheduling hypothesis, we consider parents' level of education as the best single measure of social class. Parental education may affect parental expectations/values/behaviors concerning children's time use and how effectively parents communicate these expectations to their children more directly than income-based measures. Although we recognize that income is a significant barrier to participation for poor families (e.g., Casey, Ripke, \& Huston, 2005), parents’ conceptualization, planning, and support for children’s time use may, in general, be more influenced by education.

${ }^{5}$ Proportions are based on time diary reports made by individuals at a specific time during the school year. As such, they should not be considered as an estimate of the prevalence of organized activity participation over a longer time interval (e.g., the whole school year).

${ }^{6}$ Larson and Verma's (1999) review estimates that North American youth spend 40-80 minutes/day (4.7-9.3 hours/week) in active, structured leisure activities. On average, this is more time than indicated by PSID-CDS findings. The difference probably reflects sampling and methodological issues. The review estimates represent an aggregation of studies focused on particular demographic groups. The PSID-CDS involves a nationally representative sample. The review also estimates time use through different approaches. One approach is the experience sampling method where youth carry a paging device and report on their activities by responding to randomly timed signals. This method can be biased to youth who are willing to respond to the signals consistently and who may be more engaged in general. Such youth would be expected to be more involved in organized activities. However, the time diary approach used in the PSID-CDS also has limitations. The primary restrictions are that time samples were taken at a particular time of the school year, only two days were sampled, and, like the experience sampling method, low frequency activities tend to be underestimated. 


\section{References}

Afterschool Alliance (2005). Working families and afterschool. A special report from America After 3PM: A household survey on afterschool in America. Retrieved September 18, 2005 from http://www.afterschoolalliance.org/press_archives/ Working_Families.Rpt.pdf.

Averill, P. M., \& Power, T. G. (1995). Parental attitudes and children's experiences in soccer: Correlates of effort and enjoyment. International Journal of Behavioral Development, 18, 263-276.

Barber, B. L., Eccles, J. S., \& Stone, M. R. (2001). Whatever happened to the jock, the brain, and the princess? Young adult pathways linked to adolescent activity involvement and social identity. Journal of Adolescent Research, 16, 429-455.

Borden, L. M., Perkins, D. F., Villarruel, F. A., Carleton-Hug, A., Stone, M., \& Keith, J. G. (2006). Challenges and opportunities to Latino youth development: Increasing meaningful participation in youth development programs. Hispanic Journal of Behavioral Sciences, 28, 187-208.

Boys \& Girls Clubs of America (2004). Boys \& Girls Clubs of America 2004 annual report: Making connections. Retrieved May 29, 2006, from: http://www.bgca.org/whoweare/CONNECTIONS_Annual_05.pdf.

Capizzano, J., Tout, K., Adams, G. (2000). Child care patterns of school-age children with employed mothers. Retrieved December 24, 2005 from: http://www.urban.org/url. cfm?ID=310283.

Casey, D. M., Ripke, M. N., \& Huston, A. C. (2005). Activity Participation and the well-being of children and adolescents in the context of welfare reform. In J. L. Mahoney, R. W. Larson, \& J. S. Eccles (Eds.), Organized activities as contexts of development: Extracurricular activities, after-school and community programs (pp. 65-84). Mahwah, NJ: Erlbaum.

Carruthers, C. P., \& Busser, J. A. (2000). A qualitative outcome study of boys and girls club program leaders, club members, and parents. Journal of Park and Recreation Administration, 18, 50-67.

Coleman, J. S. (1961). The adolescent society: The social life of the teenager and its impact on education. New York, NY: Free Press of Glencoe.

Cooper, H., Valentine, J. C., Nye, B., \& Lindsay, J. J. (1999). Relationships between five after-school activities and academic achievement. Journal of Educational Psychology, 91, 369-378.

Csikszentmihalyi, M., Rathunde, K., \& Whalen, S. (1993). Talented teenagers: The roots of success \& failure. New York: Cambridge University Press.

Dubois, D. L., Holloway, B. E., Valentine, J. C., \& Cooper, H. (2002). Effectiveness of mentoring programs for youth: A meta-analytic review. American Journal of Community Psychology, 30, 157-197.

Eccles, J. S., \& Barber, B. (1999). Student council, volunteering, basketball, or marching band: What kinds of extracurricular involvement matters? Journal of Adolescent Research, 14,
10-43.

Eccles, J. S., Barber, B. L., Stone, M., \& Hunt, J. (2003). Extracurricular activities and adolescent development. Journal of Social Issues, 59, 10-43.

Eccles, J. S., \& Templeton, J. (2002). Extracurricular and other after-school activities for youth. Review of Educational Research, 26, 113-180.

Eccles, J. S., Wigfield, A., Harold, R., \& Blumenfeld, P. (1993). Age and gender differences in children's achievement selfperceptions during the elementary school years. Child Development, 64, 830-847.

Eccles, J. S., Wigfield, A., \& Schiefele, U. (1998). Motivation to succeed. In W. Damon (Series Ed.) \& N. Eisenberg (Vol. Ed.), Handbook of child psychology: Social, emotional, and personality development (pp. 1011-1073). NY: John Wiley \& Sons.

Ehrle, J., \& Moore, K. A. (1999). 1997 NSAF benchmarking measures of child and family well-being. Retreieved December 27, 2005 from http://www.urban.org/url.cfm?ID=410137.

Elkind, D. (2001). The hurried child: Growing up too fast, too soon. Cambridge, MA: Da Capa Press.

Fletcher, A. C., Elder, G. H., Jr., \& Mekos, D. (2000). Parental influences on adolescent involvement in community activities. Journal of Research on adolescence, 10, 29-48.

Fredricks, J. A., Alfeld-Liro, C. J., Hruda, L. Z., Eccles, J. S., Patrick, H., \& Ryan, A. M. (2002). A qualitative exploration of adolescents' commitment to athletics and the arts. Journal of Adolescent Research, 17, 68-97.

Fredricks, J. A., \& Eccles, J. S. (2005). Family socialization, gender, and sport motivation and involvement. Journal of Sport \& Exercise Psychology, 27, 3-31.

Fountain, H. (2005, July). Summertime, and the livin' is crazy. New York Times.

Gambone, M., \& Arbreton, A. (1997). Safe havens: The contributions of youth organizations to health adolescent development. Philadelphia: Public/Private Ventures.

Gilbert, S. (1999, August 3). For some children, it's an afterschool pressure cooker. New York Times.

Girls Inc. (2004). Girls Inc. 2004 annual report. Retrieved May 29, 2006 from: http://www.girlsinc.org/ic/content/annual_report_2004.pdf.

Hansen, D., Larson, R., \& Dworkin, J. (2003). What adolescents learn in organized youth activities: A survey of self-reported developmental experiences. Journal of Research on Adolescence, 13, 25-56.

Hofferth, S. L., \& Sandberg, J. F. (2001a). Changes in American children's time use. Changes at the millennium: Where have we come from, where are we going? (pp. 193-229). Elsevier Science Ltd.

Hofferth, S. L., \& Sandberg, J. F. (2001b). How American children spend their time. Journal of Marriage and Family, 63, 295-308.

Huebner, M. A., \& Mancini, J. (2003). Shaping structured out- 
of-school time use among youth: The effects of self, family, and friend systems. Journal of Youth and Adolescence, 32, 453-463.

Huston, A. (2005). Connecting the science of child development to public policy. Social Policy Report, 19, 1-20.

Jacobs, J. E., Vernon, M. K., \& Eccles, J. (2005). Activity choices in middle childhood: The roles of gender, self-beliefs, and parent's influence. In J. L. Mahoney, R. W. Larson, \& J. S. Eccles (Eds.), Organized activities as contexts of development: Extracurricular activities, after-school and community programs (pp. 235-254). Mahwah, NJ: Erlbaum.

Kane, T. J. (2004). The impact of after-school programs: Interpreting the results of four recent evaluations. Retrieved March 7, 2006, from http://www.wtgrantfoundation.org/ usr_doc/After-school_paper.pdf

Lareau, A. (2003). Unequal childhoods: Class, race, and family life. Berkeley: University of California Press.

Larson, R. W. (2000). Toward a psychology of positive youth development. American Psychologist, 55, 170-183.

Larson, R. W., \& Verma, S. (1999). How children and adolescents spend time across the world: Work, play, and developmental opportunities. Psychological Bulletin, 125, 701-736.

Leff, S. S., \& Hoyle, R. H. (1995). Young athletes' perceptions of parental support and pressure. Journal of Youth and Adolescence, 24, 17-203.

Lugaila, Terry A. (2003). A child's day: 2000 (Selected indicators of child well-being). Current Population Reports, P70-89. U.S. Census Bureau, Washington, DC. Retrieved December 27, 2005 from: http://www.census.gov/prod/2003pubs/p7089.pdf.

Luthar, S. S., \& Becker, B. E. (2002). Privileged but pressured? A study of affluent youth. Child Development, 73, 1593-1610.

Luthar, S. S., \& Latendresse, S. J. (2005a). Children of the affluent: Challenges to well-being. Current Directions in Psychological Science, 14, 49-53.

Luthar, S. S., \& Latendresse, S. J. (2005b). Comparable risks at the socioeconomic extremes: Preadolescents' perceptions of parenting. Development and Psychopathology, 17, 207-230.

Luthar, S. S., Shoum, K. A., \& Brown, P. J. (2006). Extracurricular involvement among affluent youth: A scapegoat for “ubiquitous achievement pressures?” Developmental Psychology, 42, 583-597.

Mahoney, J. L. (2000). Participation in school extracurricular activities as a moderator in the development of antisocial patterns. Child Development, 71, 502-516.

Mahoney J. L. \& Cairns, R. B. (1997). Do extracurricular activities protect against early school dropout? Developmental Psychology, 32, 241-253.

Mahoney, J. L., Cairns, B. D., \& Farmer, T. (2003). Promoting interpersonal competence and educational success through extracurricular activity participation. Journal of Educational Psychology, 95, 409-418.

Mahoney, J. L., Larson, R. W., \& Eccles, J. S. (Eds.) (2005).
Organized activities as contexts of development: Extracurricular activities, after-school and community programs. Mahwah, NJ: Lawrence Erlbaum \& Associates.

Mahoney, J. L., Lord, H., \& Carryl, E. (2005a). An ecological analysis of after-school program participation and the development of academic performance and motivational attributes for disadvantaged children. Child Development, 76, 811-825.

Mahoney, J. L., Lord, H., \& Carryl, E. (2005b). Afterschool program participation and the development of child obesity and peer acceptance. Applied Developmental Science, 9, 201-214.

Mahoney, J. L., Lord, H., \& Stattin, H. (2004). Participation in unstructured youth recreation centers and the development of antisocial behavior: Selection processes and the moderating role of deviant peers. International Journal of Behavioral Development, 28, 553-560.

Mahoney, J. L., \& Zigler, E. F. (2006). Translating science to policy under the No Child Left Behind Act of 2001: Lessons from the national evaluation of the $21^{\text {st }}$-Century Community Learning Centers. Journal of Applied Developmental Psychology, 27, 282-294.

Marsh, H. W. (1992). Extracurricular activities: Beneficial extension of the traditional curriculum or subversion of academic goals? Journal of Educational Psychology, 84, 553-562.

Marsh, H. W., \& Kleitman, S. (2003). School athletic participation: Mostly gain with little pain. Journal of Sport \& Exercise Psychology, 25, 205-228.

Marshall, N. L., Garcia Coll, C., Marx, F., McCartney, K., Keefe, N., \& Ruh, J. (1997). After-school time and children's behavioral adjustment. Merrill-Palmer Quarterly, 43, 497514.

McCall, R. B., \& Groark, C. J. (2000). The future of applied child development research and public policy. Child Development, 71, 197-204.

McCartney, K., \& Rosenthal, R. (2000). Effect size, practical importance, and social policy for children. Child Development, 71, 173-180.

McHale, S. M., Crouter, A. C., \& Tucker, C. J. (2001). Free-time activities in middle childhood: Links with adjustment in early adolescence. Child Development, 72, 1764-1778.

McLaughlin, M. W. (2000). Community counts: How youth organizations matter for youth development. Washington, DC: Public Education Network.

Moore, K. A., Hatcher, J. L., Vandivere, S., \& Brown, B. V. (2000). Children's behavior and well-being: Findings from the National Survey of America's Families. Retrieved May 29, 2006 from: http://www.urban.org/UploadedPDF/900845_1999Snapshots. pdf.

National Research Council and Institute of Medicine. (2002). Community programs to promote youth development. Committee on Community-Level Programs for Youth. J. Eccles \& J. A. Gootman (Eds.), Board on Children, Youth, and Families, Division of Behavioral and Social Science and 
Education. Washington, DC: National Academy Press.

National Research Council and Institute of Medicine (2003). Working families and growing kids: Caring for children and adolescents. Committee on Family and Work Policies. E. Smolensky \& J. A. Gootman (Eds.), Board on Children, Youth, and Families, Division of Behavioral and Social Sciences and Education. Washington, DC: National Academies Press.

Noonan, D. (2001, January 29). Stop stressing me: For a growing number of kids, the whirlwind of activities can be overwhelming. How to spot burnout. Newsweek (pp. 54-55).

Passmore, A., \& French, D. (2001). Development and administration of a measure to assess adolescents' participation in leisure activities. Adolescence, 36, 67-75.

Perkins, D. F., Borden, L. M., Villaruel, F. A., Carlton-Hug, A., \& Stone, M. (2006). Participation in structured youth programs: Why ethnic minority urban youth choose to participate or not to participate. Manuscript submitted for publication.

Pettit, G. S., Bates, J. F., Dodge, K. A., \& Meece, D. W. (1999). The impact of after-school peer contact on early adolescent externalizing problems in moderated by parental monitoring, perceived neighborhood safety, and prior adjustment. Child Development, 70, 768-778.

Pierce, K. M., Hamm, J. V., \& Vandell, D. L. (1999). Experiences in after-school programs and children's adjustment in first-grade classrooms. Child Development, 70, 756-767.

Pittman, K., Tolman, J., \& Yohalem, N. (2005). Developing a comprehensive agenda for the out-of-school hours: Toward a theory of developmental intentionality. In J. L. Mahoney, R. W. Larson, \& J. S. Eccles (Eds.), Organized activities as contexts of development: Extracurricular activities, afterschool and community programs (pp. 399-418). Mahwah, NJ: Lawrence Erlbaum \& Associates.

Posner, J. K., \& Vandell, D. L. (1999). After-school activities and the development of low-income urban children: A longitudinal study. Developmental Psychology, 35, 868-879.

Quinn, J. (2005). Building effective practices and policies for out-of-school time. In J. L. Mahoney, R. W. Larson, \& J. S. Eccles (Eds.), Organized activities as contexts of development: Extracurricular activities, after-school and community programs (pp. 479-496). Mahwah, NJ: Lawrence Erlbaum \& Associates.

Raymore, L., Godbey, G., \& Crawford, D. (1994). Self-esteem, gender, and socioeconomic status: Their relation to perceptions of constraints on leisure among adolescents. Journal of Leisure Research, 26, 99-118.

Richardson, J., Radziszewska, B., Dent, C., \& Flay, B. (1993). Relationship between after-school care of adolescents and substance use, risk taking, depressed mood, and academic achievement. Pediatrics, 92, 32-28.

Riggs, N. R., \& Greenberg, M. T. (2004). After-school youth development programs: A developmental-ecological model of current research. Clinical Child and Family Psychology Review, 7, 177-190.

Rosenfeld, A., \& Wise, N. (2000). The over-scheduled child: Avoiding the hyper-parenting trap. New York: St. Martin's Griffin.

Rosenthal, R., \& Vandell, D. L. (1996). Quality of care of schoolaged child-care programs: Regulatable features, observed experiences, child perspectives, and parent perspectives. Child Development, 67, 2434-2445.

Scanlan, T. K. (1984). Competitive sports and the child athlete. In J. M. Silva III \& R. S. Weinberg (Eds.), Psychological foundations of sport (pp. 118-129). Champaign, IL: Human Kinetics.

Seppanen, P. S., Love, J. M., de Vries, D. K., Bernsein, L., Seligson, M., Marx, R., et al. (1993). National Study of before and after school programs: Final report. Washington, DC: U.S. Department of Education, Office of Policy and Planning. Portsmouth, NH: RMC Research Corporation.

Shonkoff, J. P. (2000). Science, policy, and practice: Three cultures in search of a shared mission. Child Development, 71, 181-187.

Simpkins, S. D., Davis-Kean, P. E., \& Eccles, J. S. (2005). Parents' socializing behavior and children's participation in math, science, and computer out-of-school activities. Applied Developmental Science, 9, 14-30.

U.S. Department of Agriculture (2003). Annual 4-H Youth Development enrollment report: 2003 Fiscal Year. Retrieved May 29, 2006 from: http://www.national4-hheadquarters. gov/library/2003-es237.pdf.

U.S. Department of Labor (2005). Women in the labor force: A databook. Retrieved December 27, 2005 from http://www. bls.gov/cps/wlf-databook2005.htm.

Vandell, D. L., Pierce, K. M., \& Dadisman, K. (2005). Out-ofschool settings as a developmental context for children and youth. In R. Kail (Ed.) Advances in Child Development. Volume 33. Oxford: Elsevier.

Vandell, D. L., \& Shumow, L. (1999). After-school child care programs. The Future of Children, 9, 64-80. Los Altos, CA: The David and Lucile Packard Foundation.

Wigfield, A., \& Eccles, J. S. (1992). The development of achievement task values: A theoretical analysis. Developmental Review, 12, 265-310.

Zaff, J. S., Moore, K. A., Papillo, A. R., \& Williams, S. (2003). Implications of extracurricular activity participation during adolescence on positive outcomes. Journal of Adolescent Research, 18, 599-630. 
Appendix A. Description of Organized and Non-Organized Activities and Rate of Participation (hours:minutes) Among Whites and Blacks (Time Diaries for CDS-II, 2002) ${ }^{\mathrm{a}}$

\begin{tabular}{|c|c|c|c|}
\hline \multirow[b]{2}{*}{ Activity } & \multirow[b]{2}{*}{ Description } & \multicolumn{2}{|c|}{ Weekly Total } \\
\hline & & Whites & Blacks \\
\hline $\begin{array}{l}\text { Organized } \\
\text { Activities }\end{array}$ & $\begin{array}{l}\text { Includes (a) sports: classes/lessons in sports/leisure activities (e.g., dance, } \\
\text { martial arts), meets/games/practices for team based and individual sports, } \\
\text { leisure participation in any sports/exercise; and (b) non-sports: volunteer/ } \\
\text { helping, religion-based, before and after school, and child/family organiz- } \\
\text { ations. }\end{array}$ & $\begin{array}{l}5: 33 \\
(6: 50)\end{array}$ & $\begin{array}{c}5: 01 \\
(6: 47)\end{array}$ \\
\hline $\begin{array}{l}\text { Educational } \\
\text { Activities }\end{array}$ & $\begin{array}{l}\text { Includes activities such as homework, being tutored, non-school profess- } \\
\text { sional classes or lectures, studying/research/reading, library activities, } \\
\text { reviewing homework with parents/caregiver, and leisure reading. }\end{array}$ & $\begin{array}{l}5: 18 \\
(6: 32)\end{array}$ & $\begin{array}{l}4: 49 \\
(4: 55)\end{array}$ \\
\hline $\begin{array}{l}\text { Household } \\
\text { Chores }\end{array}$ & $\begin{array}{l}\text { Meal preparation, serving food/setting table, washing dishes, indoor } \\
\text { cleaning/chores/housework, laundry, household repairs, other house- } \\
\text { hold activities. }\end{array}$ & $\begin{array}{c}2: 13 \\
(3: 32)\end{array}$ & $\begin{array}{c}2: 05 \\
(3: 48)\end{array}$ \\
\hline TV & Watching television. & $\begin{array}{c}13: 37 \\
(10: 53)\end{array}$ & $\begin{array}{c}17: 41 \\
(10: 19)\end{array}$ \\
\hline $\begin{array}{l}\text { Hanging } \\
\text { Out }\end{array}$ & $\begin{array}{l}\text { Includes visiting with others, parties, attending bars/ lounges/clubs, } \\
\text { going out “dancing,” other such socializing events, and travel related } \\
\text { to socializing. }\end{array}$ & $\begin{array}{l}3: 01 \\
(7: 07)\end{array}$ & $\begin{array}{r}2: 30 \\
(6: 19)\end{array}$ \\
\hline $\begin{array}{l}\text { Playing } \\
\text { Games }\end{array}$ & $\begin{array}{l}\text { Includes activities such as playing dress-up, house, card/board games, } \\
\text { jump rope, toys or dolls, and electronic video games (e.g., Nintendo). }\end{array}$ & $\begin{array}{l}7: 28 \\
(8: 37)\end{array}$ & $\begin{array}{r}6: 04 \\
(8: 20)\end{array}$ \\
\hline Attending Class & Attending classes/school if full-time students. & $\begin{array}{c}27: 26 \\
(13: 32)\end{array}$ & $\begin{array}{c}29: 18 \\
(12: 33)\end{array}$ \\
\hline \multirow[t]{3}{*}{ Personal Care } & $\begin{array}{l}\text { Night sleep/longest sleep for day, waking up/going to bed, dressing, } \\
\text { personal hygiene, meals/eating, naps. }\end{array}$ & $\begin{array}{c}82: 02 \\
(11: 33)\end{array}$ & $\begin{array}{c}81: 35 \\
(11: 48)\end{array}$ \\
\hline & Total: & 146:38 & 149.03 \\
\hline & $\begin{array}{l}\text { Percent of } \\
\text { Total Hours } \\
\text { In a Week (168) }\end{array}$ & $86 \%$ & $87 \%$ \\
\hline
\end{tabular}

Note: Analyses are weighted. Unweighted number of observations is 1144 for Whites and 981 for Blacks.

average time is not conditional upon having spent time on the activity. 
Appendix B. Time Spent on Various Activities (Hrs:Min Per Week) for Whites and Blacks by Parental Education and Age Group.

\begin{tabular}{|c|c|c|c|c|c|c|c|c|c|c|c|c|}
\hline \multirow{3}{*}{$\begin{array}{l}\text { Par. Educ. } \\
\text { Quartile }\end{array}$} & \multicolumn{12}{|c|}{ Age $5-11$} \\
\hline & \multicolumn{2}{|c|}{$\begin{array}{l}\text { Organized } \\
\text { Activities }\end{array}$} & \multicolumn{2}{|c|}{$\begin{array}{l}\text { Educational } \\
\text { Activities }\end{array}$} & \multicolumn{2}{|c|}{$\begin{array}{l}\text { Household } \\
\text { Chores }\end{array}$} & \multicolumn{2}{|c|}{$\begin{array}{c}\text { Watching } \\
\text { T.V. }\end{array}$} & \multicolumn{2}{|c|}{$\begin{array}{c}\text { Hanging } \\
\text { Out }\end{array}$} & \multicolumn{2}{|c|}{$\begin{array}{l}\text { Playing } \\
\text { Games }\end{array}$} \\
\hline & W & B & W & $\mathrm{B}$ & W & $\mathrm{B}$ & W & $\mathrm{B}$ & $\mathrm{W}$ & $\mathrm{B}$ & W & $\mathrm{B}$ \\
\hline $\mathrm{BA} / \mathrm{S}$ or $>$ & $\begin{array}{r}5: 24 \\
(5: 33)\end{array}$ & $\begin{array}{c}3: 14 \\
(6: 20)\end{array}$ & $\begin{array}{c}4: 54 \\
(4: 48)\end{array}$ & $\begin{array}{l}4: 42 \\
(3: 30)\end{array}$ & $\begin{array}{c}1: 45 \\
(2: 52)\end{array}$ & $\begin{array}{c}: 49 \\
(1: 40)\end{array}$ & $\begin{array}{l}11: 28 \\
(8: 24)\end{array}$ & $\begin{array}{l}14: 56 \\
(6: 23)\end{array}$ & $\begin{array}{c}3: 35 \\
(12: 19)\end{array}$ & $\begin{array}{l}2: 28 \\
(2: 43)\end{array}$ & $\begin{array}{l}11: 03 \\
(9: 05)\end{array}$ & $\begin{array}{c}5: 15 \\
(7: 30)\end{array}$ \\
\hline Some Col. & $\begin{array}{c}5: 13 \\
(5: 45)\end{array}$ & $\begin{array}{c}4: 15 \\
(5: 01)\end{array}$ & $\begin{array}{c}4: 46 \\
(4: 12)\end{array}$ & $\begin{array}{l}5: 25 \\
(4: 17)\end{array}$ & $\begin{array}{c}1: 59 \\
(2: 31)\end{array}$ & $\begin{array}{c}1: 17 \\
(3: 28)\end{array}$ & $\begin{array}{l}11: 40 \\
(9: 26)\end{array}$ & $\begin{array}{l}14: 31 \\
(6: 50)\end{array}$ & $\begin{array}{c}2: 10 \\
(4: 55)\end{array}$ & $\begin{array}{c}2: 52 \\
(4: 43)\end{array}$ & $\begin{array}{c}9: 30 \\
(7: 20)\end{array}$ & $\begin{array}{c}6: 20 \\
(7: 01)\end{array}$ \\
\hline H.S. & $\begin{array}{r}3: 57 \\
(6: 07)\end{array}$ & $\begin{array}{c}3: 23 \\
(5: 10)\end{array}$ & $\begin{array}{c}3: 27 \\
(4: 09)\end{array}$ & $\begin{array}{l}4: 46 \\
(4: 15)\end{array}$ & $\begin{array}{c}2: 15 \\
(3: 24)\end{array}$ & $\begin{array}{c}1: 16 \\
(2: 29)\end{array}$ & $\begin{array}{l}14: 35 \\
(10: 24)\end{array}$ & $\begin{array}{l}18: 01 \\
(8: 49)\end{array}$ & $\begin{array}{c}1: 41 \\
(3: 45)\end{array}$ & $\begin{array}{c}1: 46 \\
(4: 23)\end{array}$ & $\begin{array}{l}11: 05 \\
(9: 17)\end{array}$ & $\begin{array}{c}9: 29 \\
(9: 15)\end{array}$ \\
\hline$<$ H.S. & $\begin{array}{r}3: 09 \\
(4: 54)\end{array}$ & $\begin{array}{c}3: 33 \\
(4: 45)\end{array}$ & $\begin{array}{c}4: 21 \\
(3: 43)\end{array}$ & $\begin{array}{c}4: 47 \\
(4: 23)\end{array}$ & $\begin{array}{c}1: 13 \\
(1: 54)\end{array}$ & $\begin{array}{c}1: 42 \\
(3: 00)\end{array}$ & $\begin{array}{l}13: 40 \\
(6: 55)\end{array}$ & $\begin{array}{l}17: 06 \\
(9: 45)\end{array}$ & $\begin{array}{l}1: 15 \\
(3: 37)\end{array}$ & $\begin{array}{c}1: 34 \\
(5: 38)\end{array}$ & $\begin{array}{l}10: 57 \\
(7: 46)\end{array}$ & $\begin{array}{c}8: 11 \\
(8: 24)\end{array}$ \\
\hline Total & $\begin{array}{c}4: 43 \\
(5: 43)\end{array}$ & $\begin{array}{r}3: 34 \\
(5: 10)\end{array}$ & $\begin{array}{c}4: 21 \\
(4: 22)\end{array}$ & $\begin{array}{c}4: 57 \\
(4: 11)\end{array}$ & $\begin{array}{l}1: 54 \\
(2: 49)\end{array}$ & $\begin{array}{l}1: 21 \\
(2: 48)\end{array}$ & $\begin{array}{c}12: 38 \\
(9: 10)\end{array}$ & $\begin{array}{l}----- \\
16: 35 \\
(8: 38)\end{array}$ & $\begin{array}{l}2: 24 \\
(7: 48)\end{array}$ & $\begin{array}{c}2: 04 \\
(4: 39)\end{array}$ & $\begin{array}{l}---- \\
10: 35 \\
(8: 31)\end{array}$ & $\begin{array}{c}7: 58 \\
(8: 26)\end{array}$ \\
\hline
\end{tabular}

\begin{tabular}{|c|c|c|c|c|c|c|c|c|c|c|c|c|}
\hline & \multicolumn{12}{|c|}{ Age $12-14$} \\
\hline $\mathrm{BA} / \mathrm{S}$ or $>$ & $\begin{array}{c}8: 32 \\
(7: 26)\end{array}$ & $\begin{array}{c}4: 40 \\
(6: 27)\end{array}$ & $\begin{array}{c}8: 16 \\
(9: 11)\end{array}$ & $\begin{array}{c}5: 40 \\
(1: 58)\end{array}$ & $\begin{array}{c}2: 14 \\
(3: 49)\end{array}$ & $\begin{array}{c}1: 06 \\
(2: 15)\end{array}$ & $\begin{array}{c}13: 19 \\
(10: 41)\end{array}$ & $\begin{array}{c}17: 18 \\
(8: 11)\end{array}$ & $\begin{array}{c}2: 55 \\
(4: 29)\end{array}$ & $\begin{array}{c}: 21 \\
(1: 51)\end{array}$ & $\begin{array}{c}4: 02 \\
(6: 32)\end{array}$ & $\begin{array}{c}3: 56 \\
(3: 53)\end{array}$ \\
\hline Some Col. & $\begin{array}{c}7: 45 \\
(8: 38)\end{array}$ & $\begin{array}{c}7: 01 \\
(5: 45)\end{array}$ & $\begin{array}{c}6: 34 \\
(7: 00)\end{array}$ & $\begin{array}{c}5: 33 \\
(4: 31)\end{array}$ & $\begin{array}{c}2: 10 \\
(4: 38)\end{array}$ & $\begin{array}{r}3: 10 \\
(3: 39)\end{array}$ & $\begin{array}{c}14: 51 \\
(11: 06)\end{array}$ & $\begin{array}{c}17: 28 \\
(10: 13)\end{array}$ & $\begin{array}{c}1: 48 \\
(3: 57)\end{array}$ & $\begin{array}{c}1: 17 \\
(3: 00)\end{array}$ & $\begin{array}{r}4: 16 \\
(6: 26)\end{array}$ & $\begin{array}{c}6: 22 \\
(8: 44)\end{array}$ \\
\hline H.S. & $\begin{array}{c}5: 29 \\
(6: 44)\end{array}$ & $\begin{array}{c}6: 36 \\
(8: 23)\end{array}$ & $\begin{array}{c}4: 46 \\
(6: 00)\end{array}$ & $\begin{array}{c}4: 42 \\
(4: 06)\end{array}$ & $\begin{array}{c}2: 38 \\
(3: 10)\end{array}$ & $\begin{array}{r}2: 53 \\
(3: 25)\end{array}$ & $\begin{array}{l}15: 53 \\
(9: 37)\end{array}$ & $\begin{array}{c}22: 59 \\
(10: 59)\end{array}$ & $\begin{array}{c}1: 48 \\
(4: 46)\end{array}$ & $\begin{array}{c}: 39 \\
(2: 21)\end{array}$ & $\begin{array}{r}8: 40 \\
(9: 28)\end{array}$ & $\begin{array}{c}4: 15 \\
(5: 48)\end{array}$ \\
\hline$<$ H.S. & $\begin{array}{c}3: 54 \\
(7: 09)\end{array}$ & $\begin{array}{c}7: 22 \\
(8: 36)\end{array}$ & $\begin{array}{c}3: 50 \\
(3: 44)\end{array}$ & $\begin{array}{r}4: 00 \\
(4: 37)\end{array}$ & $\begin{array}{c}3: 54 \\
(5: 26)\end{array}$ & $\begin{array}{c}2: 08 \\
(4: 10)\end{array}$ & $\begin{array}{c}14: 27 \\
(11: 51)\end{array}$ & $\begin{array}{c}14: 37 \\
(11: 23)\end{array}$ & $\begin{array}{l}3: 02 \\
(4: 55)\end{array}$ & $\begin{array}{c}2: 46 \\
(8: 00)\end{array}$ & $\begin{array}{c}6: 43 \\
(8: 08)\end{array}$ & $\begin{array}{l}9: 08 \\
(9: 30)\end{array}$ \\
\hline Total & $\begin{array}{c}6: 47 \\
(7: 38)\end{array}$ & $\begin{array}{c}6: 19 \\
(7: 32)\end{array}$ & $\begin{array}{c}6: 21 \\
(7: 35)\end{array}$ & $\begin{array}{c}4: 55 \\
(4: 05)\end{array}$ & $\begin{array}{c}2: 34 \\
(4: 03)\end{array}$ & $\begin{array}{c}2: 32 \\
(3: 29)\end{array}$ & $\begin{array}{l}14: 27 \\
(10: 34)\end{array}$ & $\begin{array}{c}19: 29 \\
(10: 50)\end{array}$ & $\begin{array}{l}2: 17 \\
(4: 30)\end{array}$ & $\begin{array}{c}1: 05 \\
(3: 52)\end{array}$ & $\begin{array}{c}5: 58 \\
(8: 09)\end{array}$ & $\begin{array}{c}5: 36 \\
(7: 25)\end{array}$ \\
\hline
\end{tabular}

Age $15-18$

\begin{tabular}{|c|c|c|c|c|c|c|c|c|c|c|c|c|}
\hline $\mathrm{BA} / \mathrm{S}$ or $>$ & $\begin{array}{c}7: 39 \\
(8: 55)\end{array}$ & $\begin{array}{r}6: 23 \\
(6: 36)\end{array}$ & $\begin{array}{c}8: 25 \\
(9: 26)\end{array}$ & $\begin{array}{c}7: 56 \\
(7: 30)\end{array}$ & $\begin{array}{c}2: 03 \\
(4: 00)\end{array}$ & $\begin{array}{c}1: 36 \\
(3: 02)\end{array}$ & $\begin{array}{c}13: 23 \\
(14: 37)\end{array}$ & $\begin{array}{c}19: 03 \\
(10: 18)\end{array}$ & $\begin{array}{l}5: 13 \\
(8: 29)\end{array}$ & $\begin{array}{l}2: 19 \\
(4: 38)\end{array}$ & $\begin{array}{c}3: 07 \\
(6: 54)\end{array}$ & $\begin{array}{l}2: 46 \\
(4: 16)\end{array}$ \\
\hline Some Col. & $\begin{array}{c}6: 24 \\
(6: 45)\end{array}$ & $\begin{array}{r}5: 18 \\
(7: 22)\end{array}$ & $\begin{array}{c}5: 00 \\
(6: 56)\end{array}$ & $\begin{array}{c}3: 09 \\
(4: 52)\end{array}$ & $\begin{array}{c}3: 26 \\
(4: 55)\end{array}$ & $\begin{array}{c}1: 52 \\
(3: 11)\end{array}$ & $\begin{array}{c}15: 18 \\
(10: 55)\end{array}$ & $\begin{array}{c}16: 22 \\
(11: 17)\end{array}$ & $\begin{array}{l}4: 00 \\
(5: 49)\end{array}$ & $\begin{array}{c}5: 43 \\
(8: 28)\end{array}$ & $\begin{array}{c}3: 02 \\
(5: 41)\end{array}$ & $\begin{array}{l}4: 07 \\
(8: 30)\end{array}$ \\
\hline H.S. & $\begin{array}{c}4: 11 \\
(5: 40)\end{array}$ & $\begin{array}{r}6: 14 \\
(8: 15)\end{array}$ & $\begin{array}{c}4: 55 \\
(7: 22)\end{array}$ & $\begin{array}{c}3: 42 \\
(4: 29)\end{array}$ & $\begin{array}{c}2: 23 \\
(3: 33)\end{array}$ & $\begin{array}{c}3: 14 \\
(6: 18)\end{array}$ & $\begin{array}{c}13: 56 \\
(13: 09)\end{array}$ & $\begin{array}{c}18: 52 \\
(12: 05)\end{array}$ & $\begin{array}{l}4: 34 \\
(7: 25)\end{array}$ & $\begin{array}{c}4: 42 \\
(11: 22)\end{array}$ & $\begin{array}{l}3: 45 \\
(6: 17)\end{array}$ & $\begin{array}{l}4: 07 \\
(6: 21)\end{array}$ \\
\hline$<$ H.S. & $\begin{array}{c}3: 40 \\
(9: 33)\end{array}$ & $\begin{array}{r}5: 38 \\
(7: 18)\end{array}$ & $\begin{array}{c}1: 37 \\
(3: 35)\end{array}$ & $\begin{array}{c}3: 06 \\
(8: 08)\end{array}$ & $\begin{array}{c}2: 36 \\
(3: 42)\end{array}$ & $\begin{array}{c}3: 33 \\
(4: 49)\end{array}$ & $\begin{array}{c}19: 09 \\
(13: 22)\end{array}$ & $\begin{array}{c}14: 42 \\
(10: 14)\end{array}$ & $\begin{array}{l}4: 42 \\
(7: 31)\end{array}$ & $\begin{array}{l}3: 41 \\
(7: 42)\end{array}$ & $\begin{array}{c}7: 36 \\
(13: 42)\end{array}$ & $\begin{array}{c}4: 22 \\
(12: 30)\end{array}$ \\
\hline Total & $\begin{array}{r}5: 56 \\
(7: 37)\end{array}$ & $\begin{array}{c}5: 45 \\
(7: 31)\end{array}$ & $\begin{array}{c}6: 00 \\
(8: 10)\end{array}$ & $\begin{array}{c}4: 02 \\
(6: 12)\end{array}$ & $\begin{array}{c}2: 28 \\
(4: 04)\end{array}$ & $\begin{array}{c}2: 40 \\
(4: 51)\end{array}$ & $\begin{array}{c}14: 32 \\
(13: 18)\end{array}$ & $\begin{array}{c}17: 33 \\
(11: 33)\end{array}$ & $\begin{array}{l}4: 35 \\
(7: 24)\end{array}$ & $\begin{array}{c}4: 15 \\
(8: 55)\end{array}$ & $\begin{array}{c}3: 35 \\
(7: 07)\end{array}$ & $\begin{array}{c}4: 01 \\
(8: 23)\end{array}$ \\
\hline
\end{tabular}

Note: Numbers in parentheses are standard deviations. Analyses are weighted. Unweighted number of observations is 1092 for Whites and 904 for Blacks. 


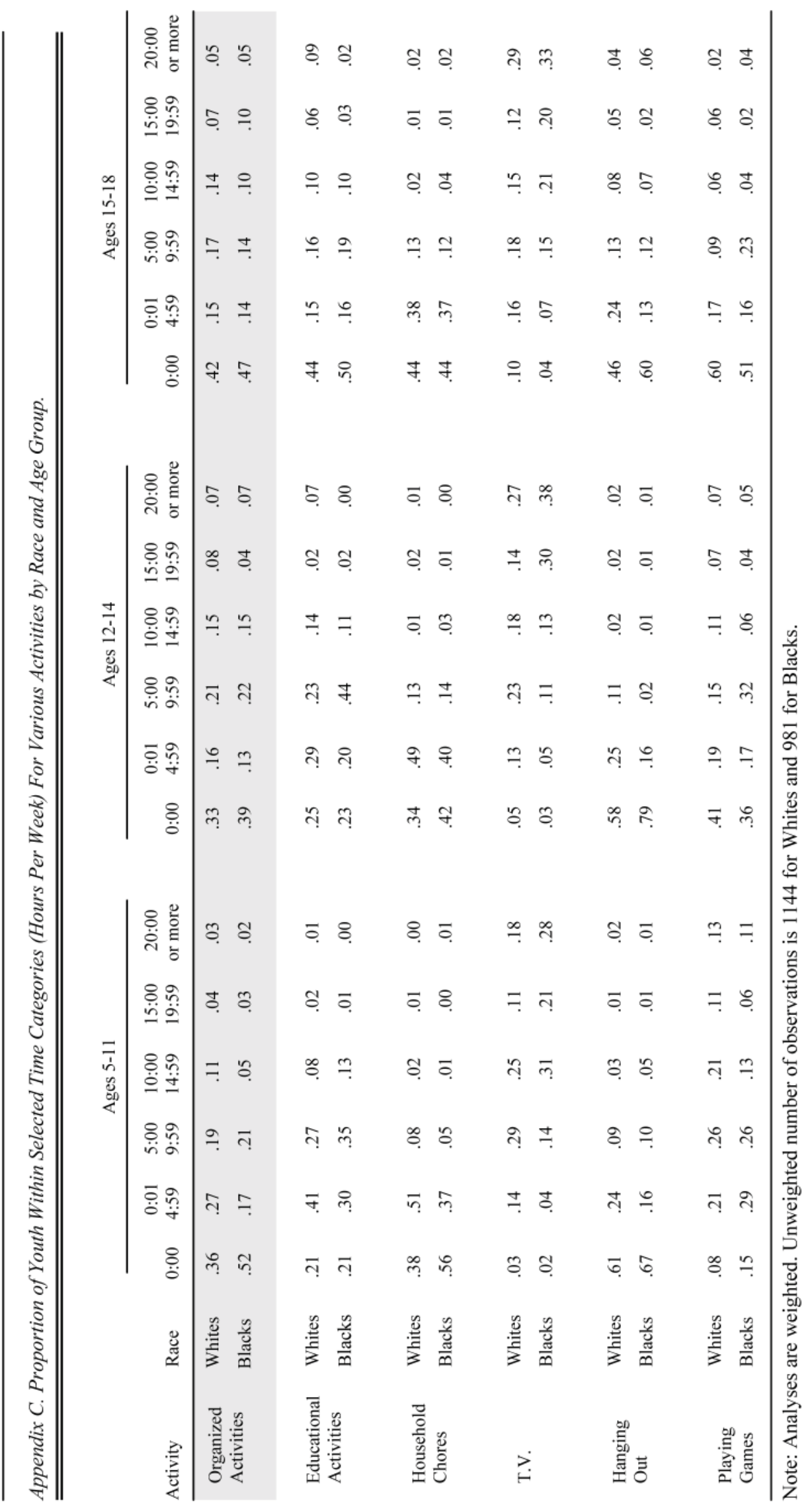


Appendix D. Description, Means, and Standard Deviations of Adolescent and Parent-Adolescent Outcomes for Whites and Blacks.

\begin{tabular}{|c|c|c|c|c|c|}
\hline \multirow[b]{2}{*}{ Variable Name } & \multirow[b]{2}{*}{ Description } & \multirow[b]{2}{*}{ Metric } & \multicolumn{2}{|c|}{ Means (SD) } & \multirow[b]{2}{*}{ Alpha } \\
\hline & & & Whites & Blacks & \\
\hline \multicolumn{6}{|c|}{ Adolescent Outcomes } \\
\hline Reading & $\begin{array}{l}\text { Summation of the Letter-Word and Passage Comprehen- } \\
\text { sion scores on the Woodcock-Johnson Achievement Test. }\end{array}$ & 0 to 194 & $\begin{array}{l}108.65 \\
(19.43)\end{array}$ & $\begin{array}{c}93.37 \\
(16.99)\end{array}$ & -- \\
\hline $\begin{array}{l}\text { Psychological } \\
\text { Well-Being }^{\text {a }}\end{array}$ & $\begin{array}{l}\text { How often did you feel (a) good at managing the respon- } \\
\text { sibilities of your daily life; (b) that you have warm and } \\
\text { trusting relationships with other kids; (c) that you have } \\
\text { experiences that challenged you to grow or become a } \\
\text { better person; (d) confident to think or express your own } \\
\text { ideas and opinions? }\end{array}$ & $\begin{array}{l}1=\text { Never } \\
6=\text { Every day }\end{array}$ & $\begin{array}{c}4.52 \\
(1.07)\end{array}$ & $\begin{array}{c}4.49 \\
(1.15)\end{array}$ & .807 \\
\hline $\begin{array}{l}\text { Global Self- } \\
\text { Esteem }\end{array}$ & $\begin{array}{l}\text { (a) Overall, I have a lot to be proud of; (b) I can do things } \\
\text { as well as most people; (c) A lot of things about me are } \\
\text { good; (d) I'm as good as most other people; (e) Other } \\
\text { people think I am a good person; (f) When I do something, } \\
\text { I do it well. }\end{array}$ & $\begin{array}{l}1=\text { Never } \\
5=\text { Always }\end{array}$ & $\begin{array}{r}4.01 \\
(.64)\end{array}$ & $\begin{array}{r}4.14 \\
(.59)\end{array}$ & .874 \\
\hline $\begin{array}{l}\text { Emotional } \\
\text { Well-Being }{ }^{\text {a }}\end{array}$ & $\begin{array}{l}\text { How often did you feel (a) happy; (b) interested in life; } \\
\text { (c) satisfied? }\end{array}$ & $\begin{array}{l}1=\text { Never } \\
6=\text { Every day }\end{array}$ & $\begin{array}{l}4.69 \\
(.98)\end{array}$ & $\begin{array}{c}4.78 \\
(1.02)\end{array}$ & .843 \\
\hline $\begin{array}{l}\text { Ever Tried } \\
\text { Cigarettes }\end{array}$ & Have you ever tried cigarette smoking, even 1 or 2 puffs? & $\begin{array}{l}0=\text { No } \\
1=\text { Yes }\end{array}$ & $\begin{array}{l}.35 \\
(.48)\end{array}$ & $\begin{array}{r}.32 \\
(.47)\end{array}$ & --- \\
\hline $\begin{array}{l}\text { Ever Drank } \\
\text { Alcohol }\end{array}$ & $\begin{array}{l}\text { Have you had a drink of beer, wine, or liquor-not just a } \\
\text { sip or a taste of someone else's drink-more than } 2 \text { or } 3 \\
\text { times in your life? }\end{array}$ & $\begin{array}{l}0=\text { No } \\
1=\text { Yes }\end{array}$ & $\begin{array}{l}.45 \\
(.50)\end{array}$ & $\begin{array}{l}.38 \\
(.49)\end{array}$ & --- \\
\hline $\begin{array}{l}\text { Ever Tried } \\
\text { Marijuana }\end{array}$ & Have you ever tried marijuana? & $\begin{array}{l}0=\text { No } \\
1=\text { Yes }\end{array}$ & $\begin{array}{l}.23 \\
(.42)\end{array}$ & $\begin{array}{c}.15 \\
(.35)\end{array}$ & --- \\
\hline \multicolumn{6}{|c|}{ Parent-Adolescent Outcomes } \\
\hline $\begin{array}{l}\text { Parent- } \\
\text { Adolescent } \\
\text { Shared } \\
\text { Activities }^{\text {a }}\end{array}$ & $\begin{array}{l}\text { Parents' response on the frequency with which they engage } \\
\text { in the following with child (a) wash or fold clothes; } \\
\text { (b) do dishes; (c) shop; (d) yard work or gardening; (e) pre- } \\
\text { pare food; (f) arts and crafts; (g) play sports or do outdoor } \\
\text { activity; (h) clean the house; (i) build or repair something; } \\
\text { (j) work or play on a computer or play video games; (k) } \\
\text { work on homework; (l) play a board game or card game or } \\
\text { do puzzles; (m) look at books or talk about books (he/she) } \\
\text { has read? }\end{array}$ & $\begin{array}{l}1=\text { Not in past month } \\
5=\text { Everyday }\end{array}$ & $\begin{array}{l}2.03 \\
(.53)\end{array}$ & $\begin{array}{r}2.21 \\
(.58)\end{array}$ & .789 \\
\hline $\begin{array}{l}\text { Eat Meals } \\
\text { With Parents }\end{array}$ & $\begin{array}{l}\text { How often does the child eat a meal with [both (you/mother/ } \\
\text { mother-figure) [and] (father/stepfather/adoptive father/father- } \\
\text { figure)]? }\end{array}$ & $\begin{array}{l}1=\text { Never } \\
7=\text { At least once a day }\end{array}$ & $\begin{array}{c}6.12 \\
(1.04)\end{array}$ & $\begin{array}{c}5.81 \\
(1.51)\end{array}$ & --- \\
\hline $\begin{array}{l}\text { Parent- } \\
\text { Adolescent } \\
\text { Favorite } \\
\text { Activity }^{\text {a }}\end{array}$ & $\begin{array}{l}\text { How often parent spent time with child doing one of (his/her) } \\
\text { favorite activities. }\end{array}$ & $\begin{array}{l}1=\text { Not in past month } \\
5=\text { Every day }\end{array}$ & $\begin{array}{c}3.10 \\
(1.05)\end{array}$ & $\begin{array}{l}2.83 \\
(1.13)\end{array}$ & --- \\
\hline $\begin{array}{l}\text { Parent- } \\
\text { Adolescent } \\
\text { Discussions }^{\text {a }}\end{array}$ & $\begin{array}{l}\text { How often parent talks to child about (a) things s/he is } \\
\text { especially interested in; (b) their relationships, like (his/her) } \\
\text { relationships with friends; (c) current events, like things } \\
\text { going on in the news; (d) (his/her) day? }\end{array}$ & $\begin{array}{l}1=\text { Never } \\
5=\text { Every day }\end{array}$ & $\begin{array}{l}3.93 \\
(.67)\end{array}$ & $\begin{array}{r}3.74 \\
(.75)\end{array}$ & 693 \\
\hline
\end{tabular}

Note: Analyses are weighted. Unweighted number of observations range from 543 to 564 for Whites and 492 to 511 for Blacks.

${ }^{a}$ Responses to these items are in reference to the past month. 
Appendix E. Means on Various Outcomes for White and Black Youth (Ages 12-18) by Time Spent on Organized Activities

\begin{tabular}{|c|c|c|c|c|c|c|c|c|c|c|c|c|}
\hline \multirow[b]{2}{*}{ Outcome } & \multirow[b]{2}{*}{ Race } & \multicolumn{6}{|c|}{ Time on Organized Activities } & \multirow{2}{*}{\multicolumn{2}{|c|}{$\begin{array}{c}\text { Partial Eta } \\
\text { Squared }\end{array}$}} & \multirow[b]{2}{*}{$\mathrm{N}$} & \multirow{2}{*}{\multicolumn{2}{|c|}{ Trend $^{\mathrm{a}}$}} \\
\hline & & 0:00 & $\begin{array}{l}0: 01 \\
4: 59 \\
\end{array}$ & $\begin{array}{l}5: 00 \\
9: 59 \\
\end{array}$ & $\begin{array}{l}10: 00 \\
14: 59 \\
\end{array}$ & $\begin{array}{l}15: 00 \\
19: 59 \\
\end{array}$ & $\begin{array}{r}20: 00 \\
\text { or more } \\
\end{array}$ & & & & & \\
\hline \multirow{2}{*}{$\begin{array}{l}\text { Reading } \\
\text { Achievement }\end{array}$} & Whites & $\begin{array}{l}107.70 \\
(.269)\end{array}$ & $\begin{array}{r}109.70 \\
(.406)\end{array}$ & $\begin{array}{l}109.63 \\
(.364)\end{array}$ & $\begin{array}{r}108.80 \\
(.437)\end{array}$ & $\begin{array}{r}111.33 \\
(.569)\end{array}$ & $\begin{array}{l}107.77 \\
(.665)\end{array}$ & 151.40 & .093 & 546 & & $Q^{* * *}$ \\
\hline & Blacks & $\begin{array}{r}90.60 \\
(.408) \\
\end{array}$ & $\begin{array}{l}92.93 \\
(.733) \\
\end{array}$ & $\begin{array}{l}97.58 \\
(.632) \\
\end{array}$ & $\begin{array}{r}97.61 \\
(.757) \\
\end{array}$ & $\begin{array}{l}94.52 \\
(.978) \\
\end{array}$ & $\begin{array}{c}94.04 \\
(1.088) \\
\end{array}$ & 54.96 & .120 & 467 & $\mathrm{~L}^{* *}$ & $\mathrm{Q}^{* * *}$ \\
\hline \multirow{2}{*}{$\begin{array}{l}\text { Psychological } \\
\text { Well-Being }\end{array}$} & Whites & $\begin{array}{c}4.29 \\
(.015)\end{array}$ & $\begin{array}{c}4.53 \\
(.023)\end{array}$ & $\begin{array}{r}4.93 \\
(.021)\end{array}$ & $\begin{array}{c}4.55 \\
(.024)\end{array}$ & $\begin{array}{c}4.60 \\
(.031)\end{array}$ & $\begin{array}{c}4.73 \\
(.038)\end{array}$ & 183.66 & .114 & 525 & $\mathrm{~L}^{* * *}$ & $\mathrm{Q}^{* * *}$ \\
\hline & Blacks & $\begin{array}{l}4.26 \\
(.027)\end{array}$ & $\begin{array}{c}4.94 \\
(.049)\end{array}$ & $\begin{array}{c}4.48 \\
(.043)\end{array}$ & $\begin{array}{l}4.48 \\
(.051)\end{array}$ & $\begin{array}{c}5.26 \\
(.066)\end{array}$ & $\begin{array}{c}4.05 \\
(.074)\end{array}$ & 76.13 & .163 & 450 & & $\mathrm{Q}^{* * *}$ \\
\hline \multirow{2}{*}{$\begin{array}{l}\text { Global Self- } \\
\text { Esteem }\end{array}$} & Whites & $\begin{array}{c}3.85 \\
(.009)\end{array}$ & $\begin{array}{c}3.93 \\
(.013)\end{array}$ & $\begin{array}{r}4.23 \\
(.012)\end{array}$ & $\begin{array}{l}4.13 \\
(.014)\end{array}$ & $\begin{array}{c}4.12 \\
(.019)\end{array}$ & $\begin{array}{l}4.13 \\
(.022)\end{array}$ & 212.38 & .127 & 538 & $\mathrm{~L}^{* * *}$ & $Q^{* * * *}$ \\
\hline & Blacks & $\begin{array}{l}4.08 \\
(.014)\end{array}$ & $\begin{array}{c}4.23 \\
(.025)\end{array}$ & $\begin{array}{c}4.25 \\
(.022)\end{array}$ & $\begin{array}{c}3.99 \\
(.026)\end{array}$ & $\begin{array}{c}4.44 \\
(.034)\end{array}$ & $\begin{array}{l}3.98 \\
(.037)\end{array}$ & 52.10 & .115 & 464 & & $\mathrm{Q}^{* * *}$ \\
\hline \multirow{2}{*}{$\begin{array}{l}\text { Emotional } \\
\text { Well-being }\end{array}$} & Whites & $\begin{array}{c}4.50 \\
(.014)\end{array}$ & $\begin{array}{c}4.61 \\
(.021)\end{array}$ & $\begin{array}{c}4.99 \\
(.019)\end{array}$ & $\begin{array}{c}4.79 \\
(.022)\end{array}$ & $\begin{array}{c}4.93 \\
(.029)\end{array}$ & $\begin{array}{l}4.91 \\
(.034)\end{array}$ & 120.54 & .078 & 528 & $\mathrm{~L}^{* * *}$ & $Q^{* * *}$ \\
\hline & Blacks & $\begin{array}{l}4.52 \\
(.025)\end{array}$ & $\begin{array}{l}4.99 \\
(.044)\end{array}$ & $\begin{array}{l}4.83 \\
(.039)\end{array}$ & $\begin{array}{l}4.91 \\
(.045)\end{array}$ & $\begin{array}{l}5.02 \\
(.058)\end{array}$ & $\begin{array}{c}5.44 \\
(.066)\end{array}$ & 58.27 & .129 & 454 & $\mathrm{~L}^{* * *}$ & \\
\hline \multirow{2}{*}{$\begin{array}{l}\text { Proportion } \\
\text { Ever Tried } \\
\text { Cigarettes }\end{array}$} & Whites & $\begin{array}{l}.38 \\
(.007)\end{array}$ & $\begin{array}{c}.41 \\
(.010)\end{array}$ & $\begin{array}{l}.33 \\
(.009)\end{array}$ & $\begin{array}{l}.25 \\
(.011)\end{array}$ & $\begin{array}{c}.31 \\
(.014)\end{array}$ & $\begin{array}{l}.26 \\
(.017)\end{array}$ & 87.38 & .057 & 533 & $\mathrm{~L}^{* * *}$ & \\
\hline & Blacks & $\begin{array}{l}.43 \\
(.012)\end{array}$ & $\begin{array}{c}.24 \\
(.020)\end{array}$ & $\begin{array}{l}.16 \\
(.018)\end{array}$ & $\begin{array}{l}.18 \\
(.021)\end{array}$ & $\begin{array}{l}.35 \\
(.027)\end{array}$ & $\begin{array}{l}.18 \\
(.030)\end{array}$ & 35.61 & .084 & 452 & $\mathrm{~L}^{* * * *}$ & $Q^{* * *}$ \\
\hline \multirow{2}{*}{$\begin{array}{l}\text { Proportion } \\
\text { Ever Drank } \\
\text { Alcohol }\end{array}$} & Whites & $\begin{array}{l}.49 \\
(.007)\end{array}$ & $\begin{array}{l}.50 \\
(.011)\end{array}$ & $\begin{array}{c}.37 \\
(.010)\end{array}$ & $\begin{array}{l}.35 \\
(.011)\end{array}$ & $\begin{array}{c}.43 \\
(.015)\end{array}$ & $\begin{array}{l}.45 \\
(.018)\end{array}$ & 80.33 & .052 & 538 & $\mathrm{~L}^{* * *}$ & $Q^{* * * *}$ \\
\hline & Blacks & $\begin{array}{c}.46 \\
(.012) \\
\end{array}$ & $\begin{array}{c}.32 \\
(.022) \\
\end{array}$ & $\begin{array}{c}.29 \\
(.019) \\
\end{array}$ & $\begin{array}{c}.29 \\
(.022) \\
\end{array}$ & $\begin{array}{c}.36 \\
(.029) \\
\end{array}$ & $\begin{array}{l}.35 \\
(.032) \\
\end{array}$ & 25.31 & .061 & 457 & $\mathrm{~L}^{*}$ & $\mathrm{Q}^{* * *}$ \\
\hline \multirow{2}{*}{$\begin{array}{l}\text { Proportion } \\
\text { Ever Tried } \\
\text { Marijuana }\end{array}$} & Whites & $\begin{array}{c}.29 \\
(.006)\end{array}$ & $\begin{array}{c}.27 \\
(.009)\end{array}$ & $\begin{array}{l}.14 \\
(.008)\end{array}$ & $\begin{array}{l}.18 \\
(.010)\end{array}$ & $\begin{array}{c}.12 \\
(.013)\end{array}$ & $\begin{array}{l}.16 \\
(.015)\end{array}$ & 67.44 & .044 & 537 & $\mathrm{~L}^{* * *}$ & $Q^{* * * *}$ \\
\hline & Blacks & $\begin{array}{c}.21 \\
(.009)\end{array}$ & $\begin{array}{l}.10 \\
(.016)\end{array}$ & $\begin{array}{c}.05 \\
(.014)\end{array}$ & $\begin{array}{l}.14 \\
(.016)\end{array}$ & $\begin{array}{l}.13 \\
(.021)\end{array}$ & $\begin{array}{c}.03 \\
(.023)\end{array}$ & 16.01 & .039 & 457 & $\mathrm{~L}^{* * * *}$ & \\
\hline \multirow{2}{*}{$\begin{array}{l}\text { Parent- } \\
\text { Adolescent } \\
\text { Shared } \\
\text { Activities }\end{array}$} & Whites & $\begin{array}{l}1.93 \\
(.007)\end{array}$ & $\begin{array}{c}2.12 \\
(.011)\end{array}$ & $\begin{array}{l}2.19 \\
(.010)\end{array}$ & $\begin{array}{l}2.04 \\
(.012)\end{array}$ & $\begin{array}{l}2.11 \\
(.016)\end{array}$ & $\begin{array}{l}1.77 \\
(.018)\end{array}$ & 106.93 & .067 & 546 & $\mathrm{~L}^{* * *}$ & $\mathrm{Q}^{* * *}$ \\
\hline & Blacks & $\begin{array}{c}2.20 \\
(.014) \\
\end{array}$ & $\begin{array}{c}2.09 \\
(.025) \\
\end{array}$ & $\begin{array}{l}2.32 \\
(.022) \\
\end{array}$ & $\begin{array}{c}2.29 \\
(.026) \\
\end{array}$ & $\begin{array}{c}2.01 \\
(.034) \\
\end{array}$ & $\begin{array}{l}2.14 \\
(.037) \\
\end{array}$ & 35.41 & .081 & 467 & $\mathrm{~L}^{*}$ & $\mathrm{Q}^{* * *}$ \\
\hline \multirow{2}{*}{$\begin{array}{l}\text { Eat/Meals } \\
\text { With Parents }\end{array}$} & Whites & $\begin{array}{c}5.99 \\
(.014)\end{array}$ & $\begin{array}{l}6.20 \\
(.022)\end{array}$ & $\begin{array}{l}6.34 \\
(.020)\end{array}$ & $\begin{array}{c}6.04 \\
(.023)\end{array}$ & $\begin{array}{c}6.35 \\
(.031)\end{array}$ & $\begin{array}{l}6.13 \\
(.036)\end{array}$ & 65.11 & .042 & 545 & $\mathrm{~L}^{* * * *}$ & $Q^{* * * *}$ \\
\hline & Blacks & $\begin{array}{c}5.82 \\
(.038) \\
\end{array}$ & $\begin{array}{c}5.51 \\
(.068) \\
\end{array}$ & $\begin{array}{l}5.92 \\
(.058) \\
\end{array}$ & $\begin{array}{c}5.88 \\
(.070) \\
\end{array}$ & $\begin{array}{c}5.81 \\
(.090) \\
\end{array}$ & $\begin{array}{c}6.30 \\
(.100) \\
\end{array}$ & 21.19 & .050 & 467 & $\mathrm{~L}^{* * *}$ & $\mathrm{Q}^{* *}$ \\
\hline \multirow{2}{*}{$\begin{array}{l}\text { Parent- } \\
\text { Adolescent } \\
\text { Favorite } \\
\text { Activities }\end{array}$} & Whites & $\begin{array}{l}2.96 \\
(.015)\end{array}$ & $\begin{array}{c}3.18 \\
(.023)\end{array}$ & $\begin{array}{l}3.33 \\
(.020)\end{array}$ & $\begin{array}{l}3.26 \\
(.024)\end{array}$ & $\begin{array}{c}3.15 \\
(.032)\end{array}$ & $\begin{array}{l}2.79 \\
(.037)\end{array}$ & 56.70 & .037 & 544 & $\mathrm{~L}^{* * *}$ & $\mathrm{Q}^{* * *}$ \\
\hline & Blacks & $\begin{array}{l}2.61 \\
(.026)\end{array}$ & $\begin{array}{l}2.17 \\
(.047)\end{array}$ & $\begin{array}{l}3.01 \\
(.041)\end{array}$ & $\begin{array}{l}3.30 \\
(.049)\end{array}$ & $\begin{array}{c}3.71 \\
(.063)\end{array}$ & $\begin{array}{l}3.07 \\
(.070)\end{array}$ & 91.15 & .185 & 466 & $\mathrm{~L}^{* * * *}$ & $\mathrm{Q}^{* * * *}$ \\
\hline \multirow{2}{*}{$\begin{array}{l}\text { Parent- } \\
\text { Adolescent } \\
\text { Discussions }\end{array}$} & Whites & $\begin{array}{l}3.81 \\
(.010)\end{array}$ & $\begin{array}{c}4.02 \\
(.014)\end{array}$ & $\begin{array}{l}3.99 \\
(.013)\end{array}$ & $\begin{array}{l}3.94 \\
(.016)\end{array}$ & $\begin{array}{c}4.02 \\
(.020)\end{array}$ & $\begin{array}{l}4.04 \\
(.024)\end{array}$ & 62.43 & .040 & 546 & $\mathrm{~L}^{* * *}$ & $\mathrm{Q}^{* * *}$ \\
\hline & Blacks & $\begin{array}{l}3.76 \\
(.019)\end{array}$ & $\begin{array}{c}3.61 \\
(.033)\end{array}$ & $\begin{array}{c}3.81 \\
(.029)\end{array}$ & $\begin{array}{l}3.70 \\
(.034)\end{array}$ & $\begin{array}{c}4.05 \\
(.045)\end{array}$ & $\begin{array}{l}3.30 \\
(.050)\end{array}$ & 36.30 & .083 & 467 & $\mathrm{~L}^{* * *}$ & $\mathrm{Q}^{* * *}$ \\
\hline $\begin{array}{l}\text { rcentage within } \\
\text { ch time categor }\end{array}$ & $\begin{array}{l}\text { White } \\
\text { Blacks }\end{array}$ & $\begin{array}{l}38 \% \\
44 \% \\
\end{array}$ & $\begin{array}{c}15-16 \% \\
13 \% \\
\end{array}$ & $\begin{array}{l}19 \% \\
18 \% \\
\end{array}$ & $\begin{array}{l}14 \% \\
12 \% \\
\end{array}$ & $\begin{array}{l}8 \% \\
7 \% \\
\end{array}$ & $\begin{array}{l}6 \% \\
6 \% \\
\end{array}$ & & & & & \\
\hline
\end{tabular}

Note: Numbers in parentheses are standard errors. Analyses are weighted. Child's sex, parental education, family income, and family structure (two-parent household) are covariates in the analysis. All comparisons are significant $(p<.001)$. Significant differences exist between categories with standard errors that do not overlap once they are subtracted and added to the means.

${ }^{a}$ For Trend analysis, $\mathrm{L}=$ linear, $\mathrm{Q}=$ quadratic, and significance levels are as follows: ${ }^{*} p<.05 * * *<.01 * * * p<.001$. 


\section{About the Authors}

Jacquelynne S. Eccles, McKeachie Collegiate Professor of Psychology at the University of Michigan, has served as President, council member, and journal editor (Journal of Research on Adolescence) for the Society for Research on Adolescence (SRA). She was also President of Division 35 of APA, a member of the DBASSE Committee of the National Academy of Science (NAS), and Chair of the NAS Committee on After School Programs for Youth. Her awards include the Spencer Foundation Fellowship for Outstanding Young Scholars in Educational Research, the APS Cattell Fellows Award for Outstanding Applied Work in Psychology, SPSSI's Kurt Lewin Award for Outstanding Research, APA Division 14 Thorndyke Award for Distinguished Life-time Research, and APA Division 7 Outstanding Mentor Award. She has conducted research on topics ranging from gender-role socialization, classroom influences on motivation to social development in the family, school, peer and wider cultural contexts.

Angel Harris is Assistant Professor of Sociology and a faculty affiliate of the Population Research Center and the Center for African and African American Studies at the University of Texas at Austin. He recently received his Ph.D. in public policy and sociology from the University of Michigan, where he was also a Post-Doctoral Fellow at the Panel Study of Income DynamicsChild Development Supplement at the Institute for Social Research. His research interests are in education, social psychology, race, and child development. His current research concentrates on the social psychological determinants of the racial achievement gap and how these factors change throughout the early stages of the life-course.

Reed W. Larson is the Pampered Chef Endowed Chair in Family Resiliency and is a professor in the Departments of Human and Community Development, Psychology, and Educational Psychology at the University of Illinois at Urbana-Champaign. His research focuses on the daily developmental experience of adolescents, particularly in the context of youth development programs and families.

Suniya S. Luthar is Professor, Developmental and Clinical Psychology and Chair, Department of Counseling and Clinical Psychology at Columbia University's Teachers College. She received her Ph.D. from Yale University in 1990. Luthar's research involves vulnerability and resilience among various populations including youth in poverty and children in families affected by mental illness. Her recent work has focused on children in affluent communities, and her findings on problems among these youth-particularly pertaining to substance use and anxiety-have received much attention in the scientific community, parents and school administrators, as well as the national media. In addition to numerous peer-reviewed journal articles, Luthar's books include Children in Poverty: Risk and Protective Forces in Adjustment; Developmental Psychopathology: Perspectives on Adjustment, Risk, and Disorder; and, most recently, Resilience and Vulnerability in Childhood: Adaptation in the Context of Adversities. Luthar is Associate Editor of the prestigious peer-reviewed journals Developmental Psychology and Development and Psychopathology and has served as Chair of a grant review committee at the National Institutes of Health. She has received several awards for her contributions to science, including a Dissertation Award and the Boyd McCandless Young Scientist Award, both from the American Psychological Association; a Research Scientist Development Award from the National Institutes of Health; and an American Mensa Education and Research Foundation Award for Excellence in Research on Intelligence.

Joseph L. Mahoney is Associate Professor in the Department of Psychology at Yale University. His research focuses on social adjustment during the school years with particular interest in children's and adolescents' use of out-of-school time. At Yale, he directs the Social Policy and Intervention Laboratory and the Yale Study of Children's After-School Time and is a faculty member of the Edward Zigler Center for Social Policy and Child Development. He is a recipient of the Public Policy Award from the Smith Richardson Foundation and served as a member of the National Academy of Science's Committee on Family and Work Policies and co-authored the resulting volume Working Families and Growing Kids (2003). He is the main editor of the volume Organized Activities as Contexts of Development (with Larson and Eccles) released in 2005.

Jodie L. Roth is a Senior Research Scientist for the National Center for Children and Families at Teachers College, Columbia University. Roth graduated from the University of Pennsylvania with a B.A. in psychology and earned both her A.M. in developmental psychology and Ph.D. from the combined program in education and psychology at the University of Michigan. Her research centers on understanding how programs and institutions affect adolescents' development. She is currently directing the After-School Time project, with funding from the William T. Grant Foundation. The project focuses on how different uses of after-school time impact adolescent development. 
Social Policy Report is a quarterly publication of the Society for Research in Child Development. The Report provides a forum for scholarly reviews and discussions of developmental research and its implications for the policies affecting children. Copyright of the articles published in the Report is maintained by SRCD. Statements appearing in the Report are the views of the author(s) and do not imply endorsement by the Editors or by SRCD.

Electronic access to the Social Policy Report is available at the Report's website: http://www.srcd.org/spr.html

Subscriptions available at $\$ 20.00$ to nonmembers of SRCD, single issues at \$5.00, and multiple copies at reduced rates. Write SRCD Executive Office (info@srcd.org) or phone (734) 998-6578.

\section{Puppose}

Social Policy Report (ISSN 1075-7031) is published four times a year by the Society for Research in Child Development. Its purpose is twofold: (1) to provide policymakers with objective reviews of research findings on topics of current national interest, and (2) to inform the SRCD membership about current policy issues relating to children and about the state of relevant research.

\section{Content}

The Report provides a forum for scholarly reviews and discussions of developmental research and its implications for policies affecting children. The Society recognizes that few policy issues are noncontroversial, that authors may well have a "point of view," but the Report is not intended to be a vehicle for authors to advocate particular positions on issues. Presentations should be balanced, accurate, and inclusive. The publication nonetheless includes the disclaimer that the views expressed do not necessarily reflect those of the Society or the editors.

\section{Procedures for Submission and Manuscript Preparation}

Articles originate from a variety of sources. Some are solicited, but authors interested in submitting a manuscript are urged to propose timely topics to the editors. Manuscripts vary in length ranging from 20 to 30 pages of double-spaced text (approximately 8,000 to 14,000 words) plus references. Authors are asked to submit manuscripts electronically, if possible, but hard copy may be submitted with disk. Manuscripts should adhere to APA style and include text, references, and a brief biographical statement limited to the author's current position and special activities related to the topic. (See page 2, this issue, for the editors' email addresses.)

Three or four reviews are obtained from academic or policy specialists with relevant expertise and different perspectives. Authors then make revisions based on these reviews and the editors' queries, working closely with the editors to arrive at the final form for publication.

The Committee on Child Development, Public Policy, and Public Information, which founded the Report, serves as an advisory body to all activities related to its publication. 